\title{
ARCHAEOLOGICAL DEPOSITS FROM THE AZTEC NEW FIRE CEREMONY
}

\author{
Christina M. Elson ${ }^{\mathrm{a}}$ and Michael E. Smith ${ }^{\mathrm{b}}$ \\ ${ }^{a}$ Department of Anthropology, American Museum of Natural History, Central Park West at 79th Street, \\ New York, NY 10024-5192, USA \\ bDepartment of Anthropology, State University of New York at Albany, Albany, NY 12222, USA
}

\begin{abstract}
The New Fire Ceremony is one of the few Aztec rituals documented in both the archaeological and historical records. The Spanish chroniclers described the New Fire Ceremony as an imperial celebration of the renewal of cosmic time that was observed on the local level by the renewal of household goods. George C. Vaillant first proposed the identification of artifact dumps at Aztec sites with descriptions of these local celebrations. We describe unpublished artifact dumps excavated by Vaillant at Chiconautla and Nonoalco in the Basin of Mexico and by Smith at Cuexcomate in Morelos and show that their context and content support Vaillant's hypothesis. Our data suggest that the New Fire Ceremony was an ancient and widespread ritual in Postclassic central Mexico that was appropriated by the Aztec empire as part of its program of ideological legitimization and control.
\end{abstract}

Our current knowledge of Aztec religion and ideology is strongly skewed toward the official state religion of Tenochtitlan. There are very few ethnohistoric descriptions of domestic or community religion, in contrast to the abundant sixteenth-century descriptions of Aztec state religion, with its complex mythology, its elaborate cosmology and iconography, and its flamboyant rituals involving human sacrifice, public processions, music, and dance. Modern scholarship has followed this trend in the available data by focusing almost exclusively on Aztec state religion (e.g., Brundage 1985; D. Carrasco 1991, 1999; Graulich 1999; Nicholson 1971b). There is little information on the extent to which the well-described state-sponsored myths, cosmology, and rituals were shared or imitated by commoners or people outside Tenochtitlan.

The lack of excavations at Aztec sites makes it difficult to establish points of contact between state and household religion. The extensive excavations at the Templo Mayor of Tenochtitlan, which provide important archaeological data on key Aztec imperial rituals (Boone 1987; Broda et al. 1987; Guilliem Arroyo et al. 1998; López Luján 1994; Matos Moctezuma 1988; Olmos Frese 1999) are not matched by excavations of residential contexts in the imperial capital. Excavations and surveys of residential sites outside Tenochtitlan, on the other hand, have yielded physical material remains of household-level rituals involving ceramic figurines, incense burners, and other objects (Brumfiel 1996; Parsons 1972; Smith 2001b), but the nature of the rituals that employed these items - and their relationship to Aztec state religion-are far from clear.

At the time of conquest, Tenochtitlan was the capital of an empire with several million subjects, and although its influence was felt throughout much of Mesoamerica, most city-states retained a great deal of local autonomy (Berdan et al. 1996; P. Carrasco 1999). Did the imperial government at Tenochtitlan con- trol the timing, practice, and content of local religious practices? Was household religion just a smaller-scale version of the welldescribed state religion taking place under the direction of local or imperial elite? Or was domestic ritual an autonomous domain only distantly related to the state and imperial religion? Scholars need to develop models explaining how state and household religion interacted if we are to address Aztec religion and ideology in a culturally dynamic way.

An examination of the ethnohistoric and archaeological evidence for rituals conducted as part of the Aztec New Fire Ceremony, a ritual of renewal conducted every 52 years, provides important new insights into the relationship between household and state religion. This is one of the few known Aztec rituals whose celebration can be documented in both state and domestic contexts, and with both ethnohistoric and archaeological data. In this article we present the ethnohistorical descriptions of state and household rituals conducted during the New Fire Ceremony and evaluate the archaeological evidence for those rituals that took place at the household level.

\section{THE XIUHTLALPILLI (NEW FIRE) CEREMONY}

The Aztecs conceived of time as cyclical, full of perpetual motion, and of themselves as a "chosen people" who collaborated with the gods to maintain the cosmic order (Leon-Portilla 1963:36-46). The Aztec calendar consisted of a 365-day secular calendar and a 260-day ritual calendar. The two calendars combined every 52 years to form a cycle similar to our century, which the Aztecs called a "bundle" of 52 years. The Aztecs believed that the world had been created and destroyed four times, and that the current age (the "fifth sun") would come to a violent end at the termination of a 52-year calendrical cycle (Taube 1993). It was not known 
which cycle would mark this destruction, and the purpose of the New Fire Ceremony was to celebrate the start of another 52-year cycle and the renewal of the world.

In addition to its role in Aztec cyclical celebrations, the New Fire Ceremony was important in Aztec conceptions of linear time. The continuous year-count annal was an Aztec historical genre that kept track of the key events in the histories of individual city-states. As analyzed by Elizabeth Boone (2000:197-237), these painted histories stressed continuity, and time was expressed in the linear arrangement of year glyphs across the pages. The origin and expansion of the Mexica empire were major themes in these histories, and the form may have originated in Tenochtitlan (Boone 2000:198). Boone notes that " $[\mathrm{t}]$ he most basic elements [in the Aztec annals], after the year count, are the sequent rulers and the binding of the years or the New Fire ceremony at the turn of the fifty-two year cycle" (Boone 2000:223). In these histories, the New Fire Ceremony played a role in tracking the histories of city-states and, most prominently, the history of the Mexica empire.

Although the native histories of the Aztecs contain numerous references to New Fire celebrations (Tena 1987), the actual ceremony is described in detail in only one source (Sahagún 19501982:Book 7:25-32), with brief mentions in several others (Códice Tudela 1980:Folio 83v-84r; Durán 1967:Book II:453-454; Gómez de Orozco 1945; Motolinía 1951). Scholarly descriptions and analyses can be found in a number of sources (Broda 1982; Brundage 1985; D. Carrasco 1999; Moedano 1951; Nicholson 1971a, 1971b; Sáenz 1967).

\section{The State Level}

On the evening of the last day of the 52-year cycle, priests climbed a hill called Huixachtlan near Culhuacan in the Basin of Mexico, where they watched the stars. When the Pleiades constellation crossed the zenith, this signaled that the sun would rise the next day to start another 52-year calendar round. Using a fire drill, the priests then started a new fire on the chest of a sacrificial victim. When the flames grew into a full fire, the victim was sacrificed, and his heart was thrown into the fire. Over the course of the day, numerous victims were offered as sacrifices (Motolinía [1951:113] gives the total as 400 ).

All fires in Aztec houses and temples had been extinguished five days previously so that people could wait for the possible end of the world. Once the priests had started the new fire on Mount Huixachtlan, signaling the renewal of the world, this flame was used to light torches that were carried by runners to all the neighborhoods and towns to relight the domestic and public fires. The temple gods were refurbished. Several scholars (Brundage 1985:9; Caso 1967:129-140; Taube 2000:315) have pointed out a symbolic association between the lighting of the new fire and the creation of the fifth sun at Teotihuacan, in which a god leapt into a bonfire to become the sun. Davíd Carrasco (1999:96-114) adds a political dimension by focusing on the prominent role played by the Mexica king Motecuhzoma in some parts of the ceremony, and on its connections to the Mexica state and empire. For example, Motolinía (1951:112) states that people had extinguished their fires "by command of the ministers of the temples." The hierarchy in the distribution of the New Fire followed the imperial order: The twin temples at the Templo Mayor received the first flames, then Huitzilopochtli's calmecac; then other temples and calmecac; then various telpochcalli; and finally individual households.
The following passage from Motolinía (1951:113) supports Carrasco's political interpretation of the distribution of the new fire:

\begin{abstract}
Thereupon, as the fire was being blessed, waiting Indians from many towns carried new fire to their temples. They did this after asking permission from the great chief of Mexico [Motecuhzoma], the pontiff who was, as it were, their pope. They performed this with great zeal and haste. Although the place might be many leagues away, they went in such haste that in a short time they placed the fire there. In the provinces distant from Mexico they performed the same ceremony and it was done everywhere with much feasting and rejoicing.
\end{abstract}

The text of the Codex Tudela (Códice Tudela 1980) also emphasizes that the new fire was carried from the palace of Motecuhzoma to a wide area, stating twice that it was distributed all over the land (después llevan el fuego a casa de Motençuma o del s[eño]r q[ue] governava y de allí se reparíia por toda la tierra, "then the fire was carried to the house [palace] of Motecuhzoma, the lord who ruled, and from there was distributed all over the land" [Códice Tudela 1980:Folio 84r; see also Gómez de Orozco 1945:62]). In Carrasco's words, “[T] his fiery display ignited the imperial landscape as well as the new time period" (D. Carrasco 1999:125). Motolinía (1951:112) mentions new fire celebrations in "Texcoco and Its Provinces," but it is not clear whether these ceremonies were an ancient Acolhua ritual or whether he was describing the celebration of the Mexica ritual in Texcoco just as it was done "all over the land."

\section{The Local Level}

The imperial celebrations of the New Fire Ceremony were matched by observances in local communities throughout the empire. On the last night of the five-day period during which the Aztecs had lived without fire and in fear of the end of the world, the people held an all-night vigil directing their unwavering attention toward Mount Huixachtlan. At the site of the distant new fire, they rejoiced. Once the new fire was lit and distributed all around, "everyone renewed his clothing and all the household goods. ... Thus it was said that truly the year newly started" (Sahagún 19501982:Book 7:31). Sahagún mentions that adults (and children) performed autosacrifice. Some commoners threw themselves into temple fires to blister themselves. At home, incense was offered.

They grasped the incense ladle, and raised it in dedication to the four directions in the courtyard. Then they cast it into the hearth. Thus incense was offered [Sahagún 1950-82:Book 7:31].

In another passage, Sahagún describes in greater detail the household rituals that took place:

First they put out fires everywhere in the country around. And the statues, hewn in either wood or stone, kept in each man's home and regarded as gods, were all cast into the water. Also (were) these (cast away) — the pestles and the three hearth stones (upon which the cooking pots rested); and everywhere there was much sweeping - there was sweeping very clean. Rubbish was thrown out; none lay in any of the houses [Sahagún 19501982:Book 7:25]. 


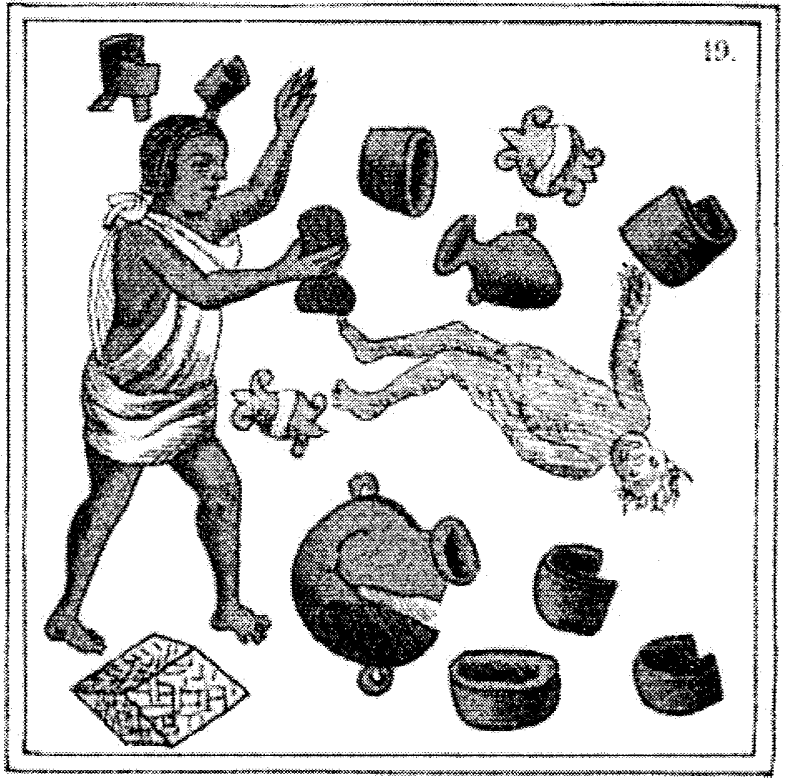

Figure 1. The dumping of domestic goods for the New Fire Ceremony (Sahagún 1950-1982:Book 7, Figure 19).

This passage was depicted by Sahagún's artists in the illustration shown in Figure 1. A similar brief description in the Codex Tudela emphasized the destruction of cooking pots:

y quebravan todas las ollas y cantaros q(ue) avian servido y los comals y basijas q(ue) tenían, todo lo quebravan [Códice Tudela 1980:Folio 83v; see also Gómez de Orozco 1945:62].

and they broke all of the jars and pitchers that had been used, and the cooking griddles and [other] vessels that they had, all were broken [authors' translation].

Why would people destroy household goods such as "statues regarded as gods," clothes, pots, pestles, incense burners, and hearth stones? We believe that these actions illustrate Aztec religious ideology. Often in Aztec religious ceremonies, a person was chosen to play the role of a divinity for a time before being sacrificed to that divinity. The impersonator, or ixiptla, was thought to become infused with the divinity's "essence." In one example from Durán discussed by López Austin (1997:33), after the impersonator of the goddess Atlan Tonan (patroness of lepers) was sacrificed, not only the body, but also any object touched by the impersonator, was destroyed because these objects were infused with the divine essence of the goddess. In Aztec ideology people, inanimate things (such as fire), and objects manufactured by humans could become infused with divine essence. This belief has been discussed regarding to the ubiquitous Aztec "idol," but other examples of objects becoming infused with divine essence include musical instruments, objects used in games, and hunting implements (Brundage 1985:67-71, López Austin 1997:28-35).

The Aztecs rejoiced at the beginning of the new century because, after passing though the dangerous year-end period, they believed that "sickness and famine have left us" (Sahagún 19501982:Book 7:31). We suggest that the Aztecs replaced some kinds of household objects because, as potential receptacles of "essences," these things no longer held desirable properties.

\section{ARCHAEOLOGY AND NEW FIRE RITUALS}

The descriptions of the New Fire Ceremony clearly document both imperial and domestic behavior. The events recorded at Mount Huixachtlan were imperial-level activities that took place only once every 52 years under the auspices of the emperor. In the household, events such as offering incense and cleaning and sweeping the hearth took place. The culmination of the 52-year cyclewhich for most people in Aztec society was a once-in-a-lifetime event-was the destruction and replacement of idols, clothes, and household utensils such as jars, pitchers, and comales.

The suggestion that certain artifact dumps reflect New Fire rituals was first proposed by George C. Vaillant in the 1930s. Unfortunately, it was presented as an integral part of a nowdiscredited model linking artifact dumps to specific historical events and ethnic groups. Vaillant $(1937,1938)$ suggested that the ethnohistorically documented destruction of household items produced archaeologically identifiable deposits of "simultaneously destroyed groups of vessels, as opposed to the more usual gradual accumulations in refuse heaps" (Vaillant 1938:552); he called these deposits "cyclical dumps." We can add some precision to Vaillant's expectations for dumps. First, New Fire artifact dumps should contain ceramic vessels that are either whole or reconstructable. There should be very few fragmentary vessels or single sherds, in contrast to middens, which consist primarily of many sherds and highly fragmented vessels. Second, the kinds of vessels found in artifact dumps should reflect a typical household assemblage, and the proportions of vessels in artifact dumps should be similar to that of middens and other domestic deposits. Third, the deposits should be unstratified and consist of a single zone of artifacts. Fourth, the deposits should be located in the vicinity of houses or house groups.

At least three sets of deposits have been interpreted as archaeological remains of New Fire celebrations. First, Vaillant (1937, 1938) identified artifact dumps at Chiconautla and Nonoalco as New Fire deposits. Unfortunately, he never published these excavations adequately. We present data later suggesting that Vaillant's interpretation of the deposits as New Fire dumps was correct, even if his larger model was not. Second, Smith (1992) excavated a number of "rock piles" at the site of Cuexcomate in Morelos, which he has interpreted as New Fire dumps. Third, Eduardo Noguera (1968) interpreted the so-called Volador offering from Tenochtitlan (also excavated in the 1930s) as a New Fire deposit, an identification that many scholars have accepted. We question this view later by showing that the Volador deposit bears little relation to either the ethnohistoric descriptions or the other archaeological examples of such deposits.

\section{Vaillant's Model}

Vaillant played a particularly active and significant role in working out the basic archaeological chronology for central Mexico. In the late 1920s, Vaillant excavated several Formative sites in the Basin of Mexico and Morelos and quickly published the site reports (Vaillant 1930, 1931, 1935a; Vaillant and Vaillant 1934), resulting in the refinement of that period. He then turned his attention to the Classic and Postclassic periods (with a particular 
Table 1. Vaillant's Aztec chronology compared with the current chronology

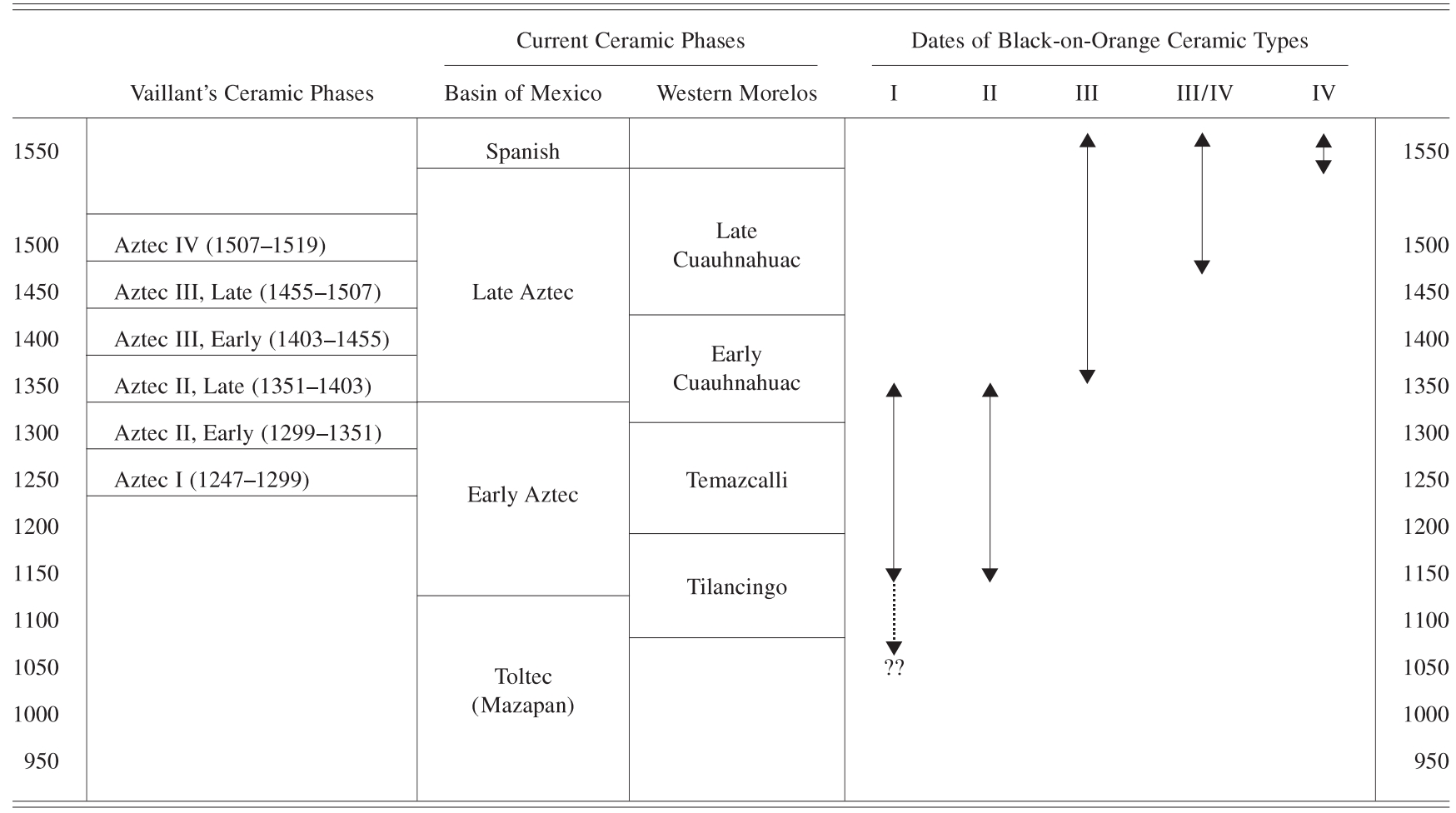

Sources: Caso (1939), Hodge and Minc (1990, 1991), Parsons et al. (1996), Smith (1996), Smith and Doershuk (1991), and Vaillant (1938, 1941).

interest in refining early Aztec history) and, in the mid-1930s, conducted a series of excavations with Suzannah Vaillant. Unfortunately, they never published the results of this fieldwork, except for a few photos and general remarks in journal articles and in George Vaillant's textbook, Aztecs of Mexico (Vaillant 1937, 1938, 1941). ${ }^{1}$ Nevertheless, Vaillant's data and interpretations influenced scholars working in central Mexico. ${ }^{2}$

In the summer and fall of 1935, while conducting fieldwork at Chiconautla and Nonoalco, the Vaillants took a course with Alfonso Caso on Mesoamerican codices and calendar systems. Several years later, Vaillant $(1937,1938)$ published a correlation of the archaeological and historical sequences in the Valley of Mexico. Using Caso's $(1939,1967)$ correlation of the Aztec and Christian calendars, Vaillant assigned absolute dates to artifact dumps and suggested that the ceramic styles in the dumps reflected the

${ }^{1}$ Vaillant's unpublished excavations include San Fransisco Mazapan, Chiconautla, Nonoalco, "Los Melones" at Texcoco, and "El Corral" at Santiago Ahuitzotla. His failure to publish his Classic and Postclassic excavations is particularly puzzling after his diligence and speed in producing high-quality site reports on the Formative sites. His notes and major artifact collections are available for consultation at the American Museum of Natural History (AMNH) in New York, and many scholars have examined these over the years. Elson has been working on the materials from Chiconautla and Nonoalco (Elson 1999).

${ }^{2}$ Vaillant counted Alfonso Caso, Manuel Gamio, Sigvald Linné, Ignacio Marquina, and Eduardo Noguera among his friends and colleagues. His notes and correspondence at the AMNH show that over dinner, visits to one another's excavations, and conferences they exchanged information and ideas. material culture of particular ethnic groups (e.g., Aztec I Blackon-Orange pottery was made and used by the "Chichimecs"). ${ }^{3}$

In the mid-1950s, the ethnohistorian H. B. Nicholson (1955:599_ 601) critiqued Vaillant's attempt to link material culture to specific ethnic groups as too simplistic (see also Nicholson 1971a). Research on the periodization of Aztec ceramics showed that Vaillant's correlation of Black-on-Orange types with 52-year-long ceramic phases also was too simplistic (Table 1). Independent research by José Luis Franco (1949:185-187) and Vaillant on the motifs of Black-on-Orange ceramics established the basic chronology still used today (Hodge 1998; Hodge and Minc 1990; Parsons 1966); however, we now know that key types such as Aztec I and Aztec II Black-on-Orange are not chronologically distinct (see also Griffin and Espejo 1947, 1950) but, rather, coeval (Hodge 1998; Whalen and Parsons 1982). ${ }^{4}$ Aztec I and Aztec II types date to the mid-

\footnotetext{
${ }^{3}$ Vaillant also suggested that the cyclical reconstructions of some religious structures were manifestations of New Fire activities. At Tenayuca (excavated in the 1930s by Alfonso Caso, Eduardo Noguera, and Ignacio Marquina), Marquina (1951:164-180) documented six successive construction episodes. Based on the ceramic types in the fill between each layer, Vaillant (1941:81-82) suggested that the temple was refurbished every 52 years in conjunction with the celebration of the New Fire Ceremony.

${ }^{4}$ Both Vaillant and Franco suggested that Aztec I began in the midthirteenth century, and that the beginning of the fifteenth century marked the dividing line between Aztec II and III. But Franco suggested that Vaillant's 52-year ceramic periods were problematic because stylistic changes were more gradual, especially from Aztec I to II, which Franco thought coexisted from 1299 to 1351, and Aztec II to III, which he suggested coexisted from 1403 to 1455 .
} 


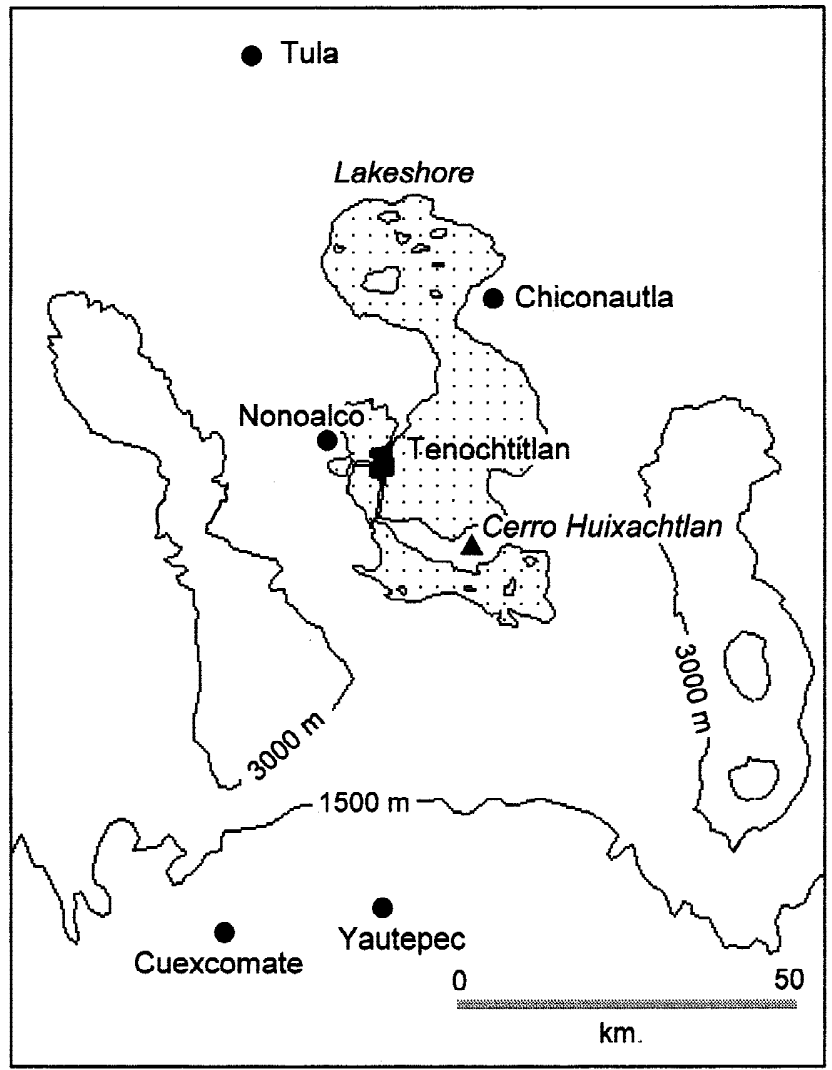

Figure 2. Map of central Mexico showing the location of sites mentioned in the text.

twelfth century, and the transition from the Early Aztec period (with the Aztec I and II types) to the Late Aztec period (with Aztec III and IV types) occurred in the mid-fourteenth century. ${ }^{5}$

A third difficulty with Vaillant's model is that he seemed to assume that only one archaeological dump would be created for each New Fire Ceremony. This is not explicitly stated, but he made a major effort to find one archaeological deposit for every New Fire date listed in the historical sources. Although researchers have discarded Vaillant's chronology of 52-year ceramic phases, archaeologists and historians (Franco 1949:184; Nicholson 1955:600) have suggested that documenting contemporaneous archaeological examples of dumps from different parts of the valley could substantiate Vaillant's hypothesis suggesting that artifact dumps were a manifestation of the New Fire Ceremony.

\section{Excavation and Content of Ritual Dumps}

Two sites with proposed New Fire dumps are located in the Basin of Mexico on the eastern (Nonoalco) and western (Chiconautla) edge of Lake Texcoco. The third site, Cuexcomate, is in western Morelos (Figure 2). The so-called Volador deposit excavated in Mexico City by Noguera has been interpreted by some as a New

${ }^{5}$ Aztec I might go back to the ninth or tenth century A.D. and in some parts of the valley pre-date Aztec II (Parsons et al. 1996).
Fire dump. We provide a brief ethnohistoric description and an overview of the archaeological work conducted at these sites, focusing on the excavations of the dumps. Then we describe the contents of these features. ${ }^{6}$

We employ a form-based functional classification of ceramics with six major categories, each of which has numerous constituent functional types. The six major categories are: serving vessels (bowls, plates, cups, pitchers, and miniature vessels); kitchen vessels (jars, griddles, basins, grinding bowls, and ladles); ritual objects (censers, figurines, sculptures, and a variety of small ceramic objects such as bells, whistles, and pipes); production tools (spindle whorls, spinning bowls, molds, and sherd scrapers); and other domestic items (a catch-all category). This classification, which is presented in more detail in Smith (2001a), is derived from Smith's form-based classification of Postclassic ceramics from Morelos (Smith 2002).

Table 2 presents the ceramic inventories of the ritual dumps at Chiconautla, Nonoalco, and Cuexcomate, organized by functional types and categories. These inventories are fundamentally domestic in character: Serving and kitchen vessels predominate, with low frequencies of vessels and objects used in domestic ritual, textile production, and other activities. They are nothing like the inventories of ceramic vessels in Aztec public ceremonial contexts such as the Templo Mayor offerings, the Volador deposit of Tenochtitlan, or various burials and caches in public contexts at sites in Morelos (Smith 2002). The ceramics in such public contexts are generally whole vessels instead of sherds, and they emphasize either drinking vessels or special-offering vessels (see Smith et al. [2002] for comparisons of vessel inventories from these public contexts).

The similarities in ceramic inventories between ritual dumps and domestic ceramics are explored in Table 3. For Cuexcomate, the dumps are compared with the houses from their patio group. For Chiconautla, the dump is compared with two other units in the elite residence, but for Nonoalco there is no good comparative deposit. These tables also include the ceramic vessels from the Volador deposit.

\section{Chiconautla}

Chiconautla is located about $17 \mathrm{~km}$ northwest of the Acolhua capital, Texcoco. At the time of the Spanish Conquest, Chiconautla was a town with its own tlatoani (Hodge 1984:Table 2-1). Vaillant (1935b) excavated a structure at the site that he interpreted as an elite residence. Elson's (1999) recent analysis of the size and layout of the building and the kind of artifacts associated with the structure supports Vaillant's interpretation and suggests that the building could have been the palace of the local tlatoani. As such, it would have been the focus of administrative, religious, and domestic activities.

Vaillant began excavations in the South House with a large trench that cut into the dump. The focal point of the ritual dump was the patio of the South House, but the dump spread through much of the house (Figures 3 and 4). Some rooms were filled with heavy concentrations of ash and large sherds. The dump extended slightly north and east outside the South House Rooms 10, 12, and

\footnotetext{
${ }^{6}$ It should be noted that only ceramic data were included in this analysis. Vaillant did not record good provenience information for all obsidian and stone at Chiconautla or Nonoalco, and the shell, bone, and plant remains have not been studied in detail.
} 
Table 2. Ceramic inventories of ritual dumps (\%total sherds)

\begin{tabular}{|c|c|c|c|c|c|}
\hline \multirow[b]{2}{*}{ Ceramic Category } & \multirow[b]{2}{*}{ Chiconautla } & \multirow[b]{2}{*}{ Nonoalco } & \multicolumn{3}{|c|}{ Cuexcomate } \\
\hline & & & 245 & 222 & 224 \\
\hline \multicolumn{6}{|l|}{ Serving } \\
\hline Plain bowl & 22.3 & 11.1 & 19.5 & 24.6 & 26.2 \\
\hline Decorated bowl & 15.3 & 8.3 & 7.3 & 5.2 & 13.5 \\
\hline Tripod plate & 19.5 & 12.4 & 0 & 0 & 0 \\
\hline Pitcher & 1.1 & 1.4 & 0 & .3 & .4 \\
\hline Copa & 1.7 & 2.9 & .4 & .3 & .4 \\
\hline Eroded bowl & 0 & 0 & 20.6 & 18.1 & 4.4 \\
\hline \multicolumn{6}{|l|}{ Kitchen } \\
\hline Jar & 5.1 & 7.3 & 2.3 & 2.5 & 5.1 \\
\hline Basin & 6.9 & 11.8 & 0 & .6 & .5 \\
\hline Comal & 16.3 & 29 & 33.6 & 34.3 & 41 \\
\hline Salt vessel & 2.8 & 2.9 & 3.8 & 5 & 2.2 \\
\hline Ladle & .1 & 0 & 0 & 0 & 0 \\
\hline \multicolumn{6}{|l|}{ Ritual } \\
\hline Censer & 1.3 & 8.7 & 9.2 & 6.9 & 1.9 \\
\hline Figurine & 3.1 & 2 & .4 & 0 & .3 \\
\hline Temple model & .2 & .1 & 0 & 0 & 0 \\
\hline Brazier & .1 & 0 & .4 & 0 & 6 \\
\hline Massive bowl & .1 & .1 & 0 & 0 & 0 \\
\hline Stamp & .1 & .1 & 0 & 0 & .1 \\
\hline Whistle & .3 & 0 & 0 & 0 & .1 \\
\hline Rattle & .2 & .5 & 0 & 0 & 0 \\
\hline Pipe & .2 & .2 & 0 & 0 & 0 \\
\hline Bell & .1 & 0 & 0 & 0 & 0 \\
\hline Flute & .1 & .1 & 0 & 0 & 0 \\
\hline \multicolumn{6}{|l|}{ Production } \\
\hline Spinning bowl & .8 & 1 & 1.1 & 1.7 & 1.7 \\
\hline Spindle whorl & 1.5 & 0 & .8 & .6 & .9 \\
\hline Worked sherd & .1 & .2 & 0 & 0 & .1 \\
\hline \multicolumn{6}{|l|}{ Other } \\
\hline Miniature vessel & .8 & 0 & 0 & 0 & .1 \\
\hline Tiny vessel & 0 & 0 & .4 & 0 & 0 \\
\hline Ball & 0 & .1 & 0 & 0 & 0 \\
\hline Bead & 0 & 0 & .4 & 0 & 0 \\
\hline Fragments & .1 & .1 & 0 & 0 & .3 \\
\hline Total sherds & 5,252 & 1,328 & 262 & 362 & 2,878 \\
\hline
\end{tabular}

Note: All figures are counts of sherds except for the Jar category, which includes only rim sherds. This unusual form of quantification is required due to the nature of the ceramic data recorded by Vaillant.

13, where the refuse was intermingled with wall fall and debris from the destruction of the South House.

In the field, Vaillant (1935b:27-29) noted that most of the Blackon-Orange sherds in the dump were Period III-IV types, and analysis of the ceramics supports his suggestion (Elson 1999:Table 1). The density of the ceramic deposit and the condition of the material in the South House distinguishes this part of the elite residence from the rest of the palace (see Vaillant 1937, 1941:Plate 32 , second row, for illustrations of complete vessels found in the South House). ${ }^{7}$ It appears that the artifact dump was created dur-

${ }^{7}$ It is not possible to quantify the number of sherds per cubic meter from the three structures; however, Vaillant's field notes, drawings, scale sections, and photographs make it clear that the volume of the excavated area did not vary enough in the three locations to be significant (see also Elson [1999:Table 2] for the size of the three structures). ing a one-time event, then sealed under the demolished South House; a platform subsequently was constructed over the house remains.

There are more miscellaneous artifacts such as hollow and solid female figurines and spindle whorls in the dump than in the Late East House or the North House (Elson 1999:Tables 3 and 4). Aztec female figurines were most likely used in household rituals (Smith 2001b), and we have noted the destruction of these "idols" as part of the New Fire celebrations.

\section{Nonoalco}

Vaillant's notes provide much less information on his excavations at Nonoalco, and there is little historical information about the site. Calnek (1976:Map 20) represents the site as almost a neighborhood of Tlatelolco. In a letter to Clarence Hay dated January 5, 1935, Vaillant stated that his excavations were located one hundred yards east of the church of San Miguel Nonoalco (which probably was constructed above a pre-Hispanic temple) and were bordered on the north by the Calzada de Nonoalco (which in pre-Hispanic times was the causeway to Azcapotzalco). Given Vaillant's description of the site, the location he dug roughly corresponds with a site that Sanders et al. (1979:Map 18) place on the lake shore between Tlatelolco and Tlacopan, where the causeway from Azcapotzalco joined the causeway connecting Tlatelolco and Tlacopan.

By Vaillant's day, this area was urbanized, and Vaillant took advantage of the little open space that was left by excavating trenches under electrical towers that ran across the site (Vaillant 1935b: Plate 1). His first trenches were in the lakebed and produced almost no material. After moving farther north, he opened the East Trench, which measured $20 \mathrm{~m}$ long on the north-south axis and $3.5 \mathrm{~m}$ wide. He did not locate the remains of a structure, but he did find the remains of a "canal" sealed under $1.2 \mathrm{~m}$ of stratigraphic deposits (Figures 5 and 6) that was filled with black clay and contained whole vessels and sherds that could be reassembled into whole or nearly whole vessels (Vaillant 1941:Plate 32). ${ }^{8}$

Vaillant states that most of the Black-on-Orange ceramics in the Nonoalco artifact dump corresponded to his Period Late III. Stratigraphically, above this deposit and slightly to the north he found a midden resulting from gradual accumulation and architectural remains, suggesting that he was digging near an area of residences. The midden contained a high frequency of Blackon-Orange pottery with naturalistic decorations, some of which were clearly European-influenced. Thus, Vaillant suggested that the ritual dump dated to the A.D. 1507 New Fire Ceremony-the last one celebrated before the arrival of the Spaniards (letter to Ignacio Marquina, January 24, 1936, Archives, Anthropology Department, American Museum of Natural History).

We lack context for the artifact dump at Nonoalco, but the kinds of ceramics in the dump and the frequency with which they occur is similar to the other artifact dumps. The majority of the artifacts are plain and decorated serving wares and kitchen wares (bowls, jars, basins, and comals) with low frequencies of artifacts used for ritual or production. Nonoalco and Cuexcomate Units 245 and 222 contain a higher frequency of censers than the other

\footnotetext{
${ }^{8}$ Using Vaillant's notes and ceramic counts in the field, we have identified discrete proveniences associated with the dump. Very probably this is only a portion of the material that could be classified as part of the artifact dump, but Vaillant's field notes are not always clear.
} 
Table 3. Comparisons of ritual dumps and middens (\%total sherds)

\begin{tabular}{|c|c|c|c|c|c|c|c|c|}
\hline & $\begin{array}{l}\text { Plain } \\
\text { Serving }\end{array}$ & $\begin{array}{l}\text { Decorated } \\
\text { Serving }\end{array}$ & $\begin{array}{l}\text { Eroded } \\
\text { Bowls }\end{array}$ & Kitchen & Ritual & Production & Other & $\begin{array}{c}\text { Total } \\
\text { Sherds }\end{array}$ \\
\hline \multicolumn{9}{|l|}{ Cuexcomate } \\
\hline \multicolumn{9}{|l|}{ Patio Group 3} \\
\hline House 1 (Unit 214) & 46.3 & 5.9 & 8.2 & 34.3 & 3.5 & .9 & .9 & 341 \\
\hline House 2 (Unit 215) & 26.1 & 8.6 & 19.7 & 42.1 & 1.4 & 1.9 & .3 & 701 \\
\hline House 3 (Unit 270) & 26.3 & 8 & 25.0 & 35.1 & 1.6 & 1.4 & 2.5 & 1,046 \\
\hline Dump (Unit 245) & 19.5 & 7.6 & 20.6 & 39.7 & 9.9 & 1.9 & .8 & 262 \\
\hline \multicolumn{9}{|l|}{ Patio Group 9} \\
\hline House (Unit 258) & 30 & 10 & 8.1 & 46.2 & 1.7 & 2.2 & 1.7 & 689 \\
\hline Dump (Unit 222) & 24.5 & 5.8 & 18.1 & 42.3 & 6.9 & 2.5 & 0 & 364 \\
\hline \multicolumn{9}{|l|}{ Patio Group 10} \\
\hline House 1 (Unit 201) & 23.9 & 12.6 & 6.3 & 40.8 & 3 & 4.1 & 9.3 & 6,344 \\
\hline House 2 (Unit 202) & 25 & 11.3 & 19.2 & 39 & .6 & 3.1 & 1.8 & 639 \\
\hline House 3 (Unit 203) & 20.3 & 17.1 & 17.7 & 41.6 & 2 & .8 & .4 & 502 \\
\hline Dump (Unit 224) & 26.2 & 14.4 & 4.4 & 48.9 & 3 & 2.7 & .5 & 2,878 \\
\hline \multicolumn{9}{|l|}{ Chiconautla } \\
\hline East & 16.3 & 43.6 & & 37.8 & .6 & .6 & 1.2 & 1,587 \\
\hline North & 15 & 45.4 & & 37.4 & 1.9 & .3 & 0 & 2,075 \\
\hline South & 25.4 & 29 & & 40 & 3 & 1.4 & 1.2 & 21,807 \\
\hline Dump & 24 & 40.5 & & 32.3 & 1.5 & .9 & .9 & 4,882 \\
\hline \multicolumn{9}{|l|}{ Nonoalco } \\
\hline Dump & 11.5 & 22.9 & & 52.6 & 12 & 1 & 0 & 1,280 \\
\hline Volador & .2 & 95.9 & & 2.3 & 1.1 & 0 & .4 & 897 \\
\hline
\end{tabular}

Note: See note to Table 2 on the quantification of jars.

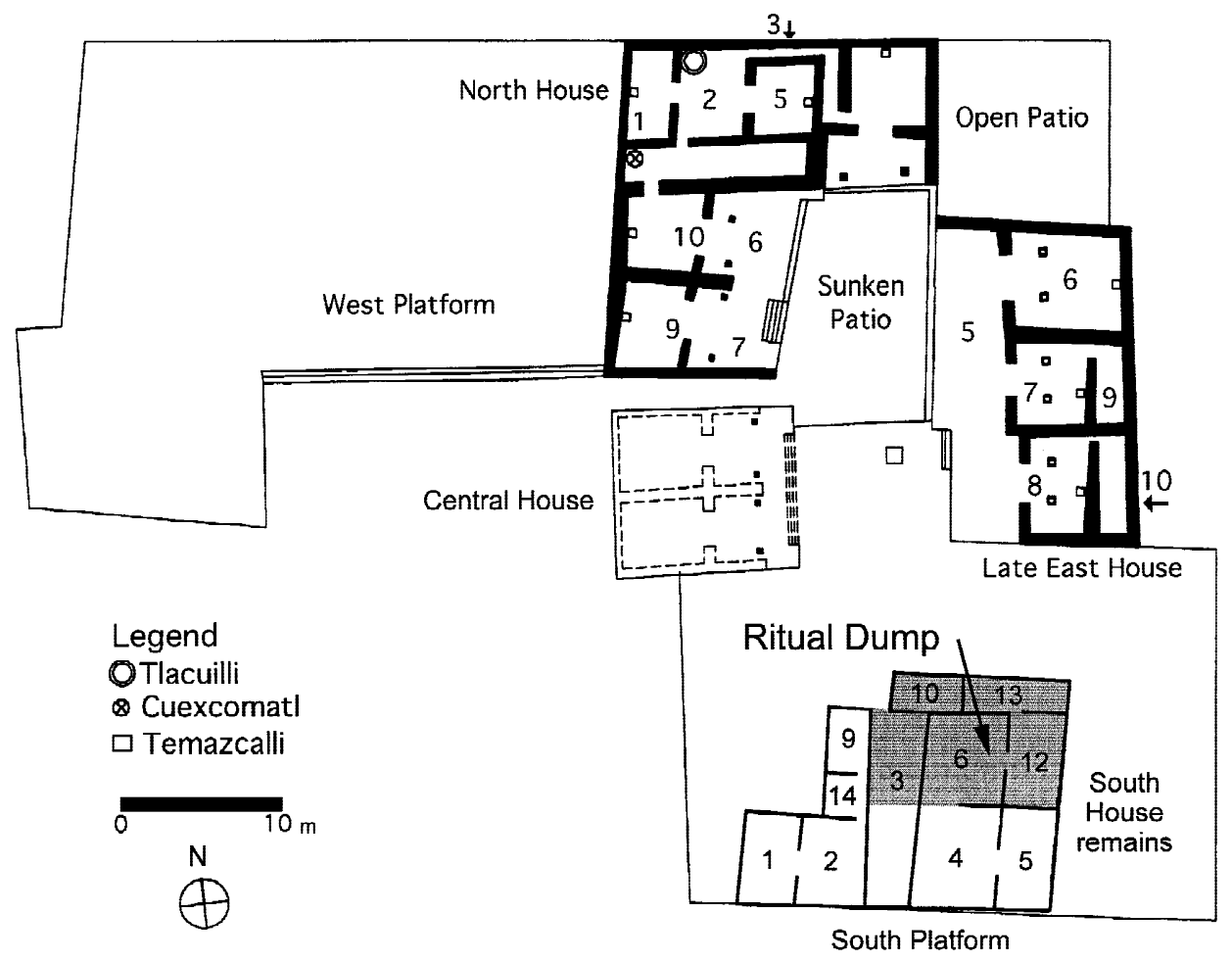

Figure 3. Plan of the elite residence at Chiconautla. 
a

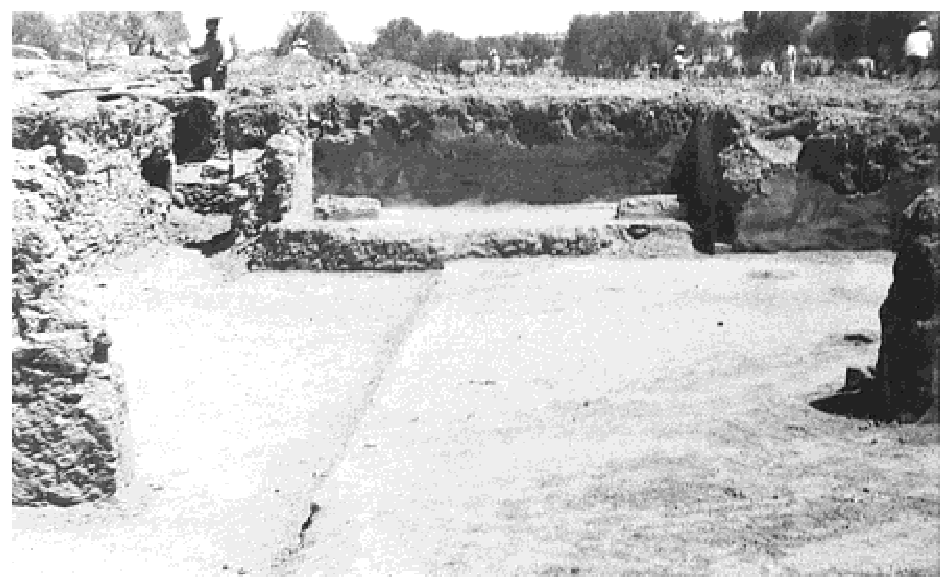

b

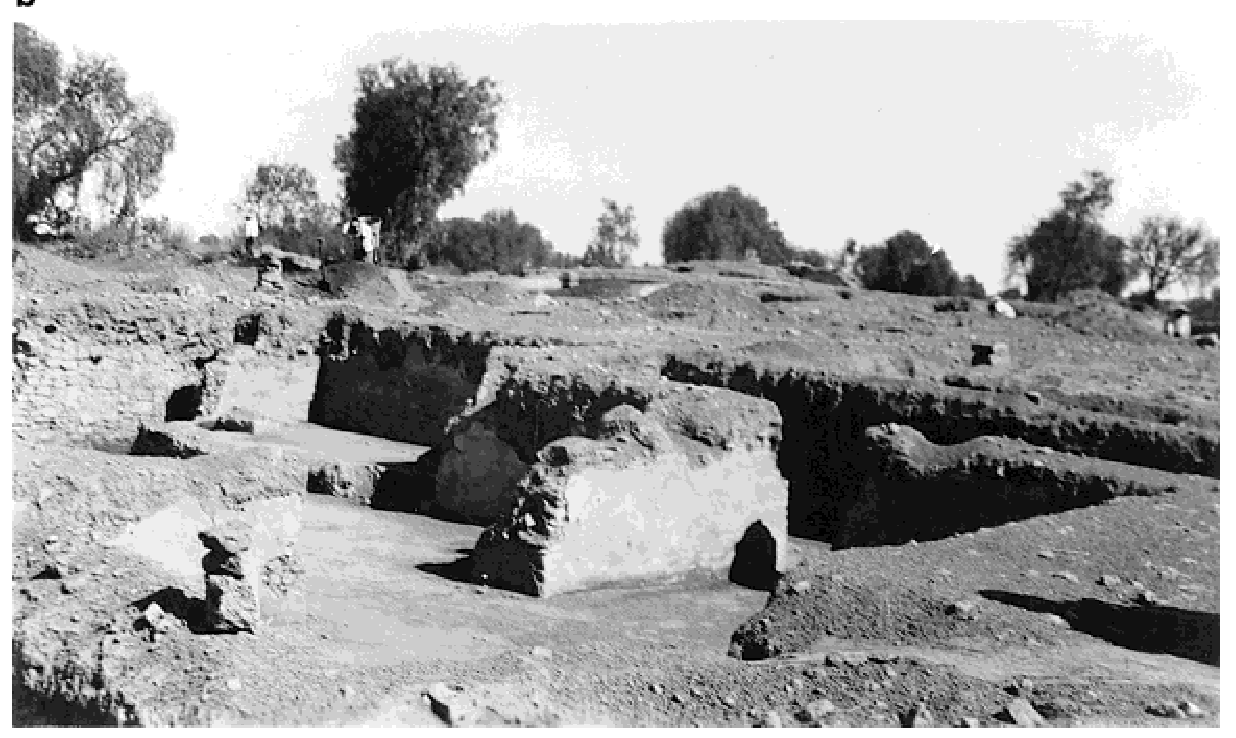

Figure 4. Photo of South House excavations at Chiconautla. (a) Rooms 3, 6, and 10, looking north; (b) Rooms 6, 10, 12, and 13 , looking northwest. dump locations. At Nonoalco, these long-handled censers were found in a very good state of preservation. None is whole, but the collection Vaillant bought back includes handles measuring 15 to $38 \mathrm{~cm}$ long, bowls that are one-third complete, and whole serpent heads and bowtie appliqués commonly found at the ends of the handles of censers. The role of incense burners in the New Fire celebrations was discussed earlier.

\section{Cuexcomate}

Cuexcomate, a small Aztec town with about 900 inhabitants in western Morelos, was occupied during the Late Postclassic period (Smith 1992; Smith and Heath-Smith 1994). At the center of the settlement was a public plaza surrounded by two elite residences, a small temple, and a special residential compound. Residential areas were distributed along a sloping ridgetop on either side of the site center. House walls are visible on the ground surface, and it was possible to map the entire community prior to excavation. Most houses formed parts of patio groups consisting of two to four houses arranged around a patio. The ritual dumps were visible as circular scatters of rocks located in the centers or at the edges of patio groups. These features were called rock piles during excavation and analysis, and subsequent artifact analyses and ethnohistoric comparisons suggested their functions as ritual dumps (Smith 1992:369-373).
Ritual dumps were identified at five of the 25 patio groups at Cuexcomate; three groups had one dump, one group had two dumps, and one group had five dumps. "Site 3," an isolated patio group in a zone of agricultural terraces $1 \mathrm{~km}$ from Cuexcomate (probably a farmstead), also had a ritual dump. The village site of Capilco, $3 \mathrm{~km}$ away, did not have any ritual dumps (Smith 1992). Figure 7 shows two patio groups at Cuexcomate with ritual dumps that were excavated in 1986. Group 3 had one ritual dump (Unit 245), and Group 10 had five dumps, one of which (Unit 224) was fully excavated. One other dump, Unit 222 in Patio Group 9, was also excavated extensively, and four other dumps were tested with small excavations.

Figure 8 (Unit 245) gives an idea of the appearance of most ritual dumps at Cuexcomate prior to excavation; Figure 9 shows the stratigraphy of Units 224 and 245. These features consist of a layer of stones covering an unstratified deposit with very dense broken domestic objects. The artifact deposits lie in shallow pits excavated into the sandy clay B-horizon soils at Cuexcomate; in some cases the pits extended into the C-horizon hardpan (known as tepetate in central Mexico). Of the seven tested dumps, one had a burial of a juvenile under the artifact deposit (Figure 9), and four had caches or offerings of ceramic serving bowls located either under the artifact deposit or adjacent to the dump.

Three characteristics of the artifact deposits in the ritual dumps stand out in comparison to the middens adjacent to residential 


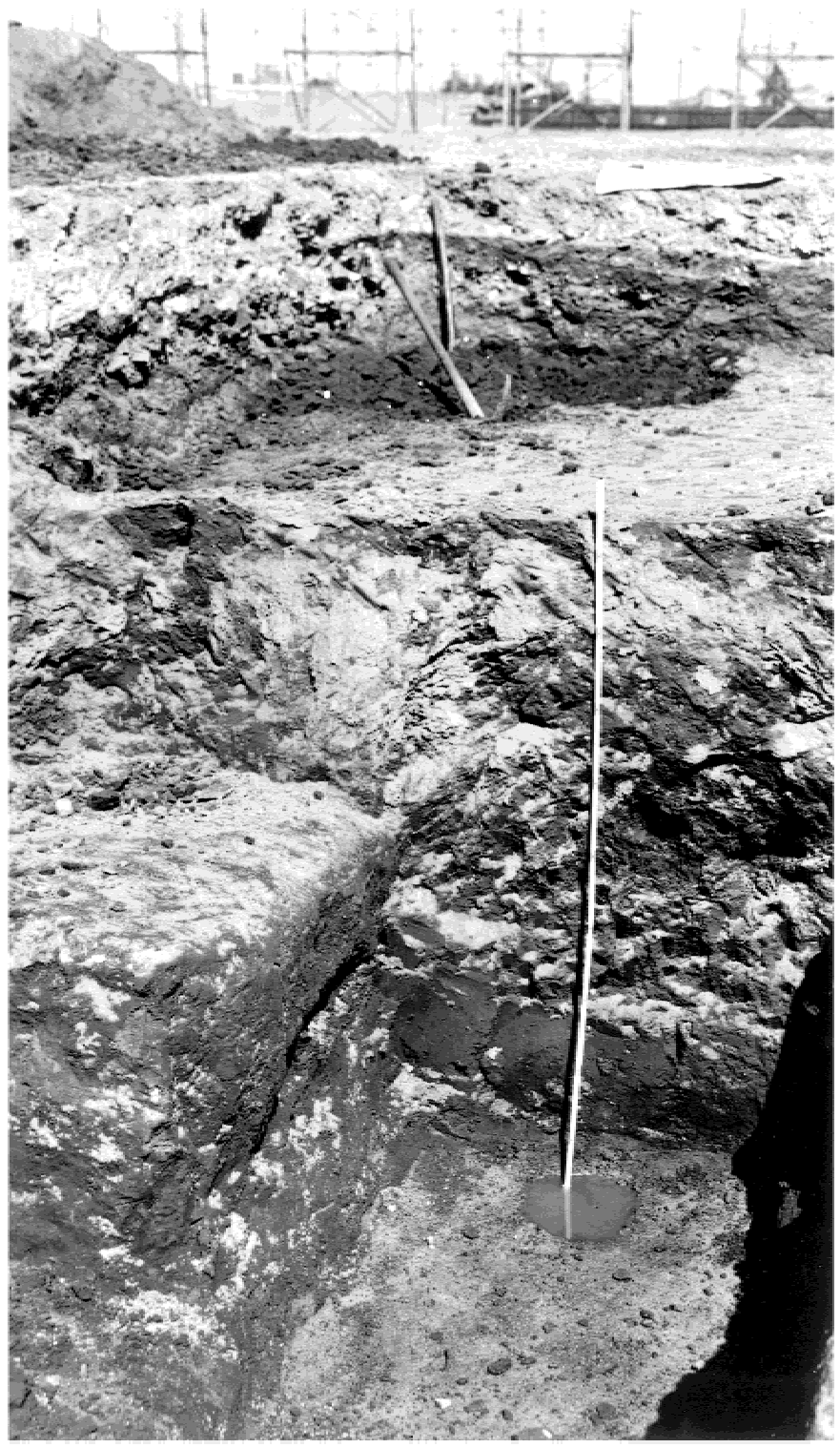

\section{power plant refuse}<smiles>CCCC</smiles>

\section{sandy soil and small sherds}

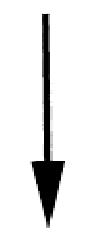

\section{black clay and large sherds}

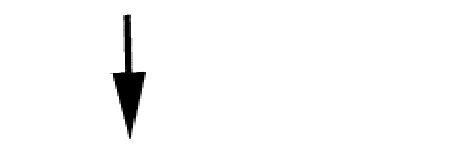

sand

Figure 5. Photo and stratigraphy of the East trench at Nonoalco.

structures at Cuexcomate. First, the density of artifacts is much higher than in middens. The mean ceramic density of Late Cuauhnahuac phase middens is 1,100 sherds $/ \mathrm{m}^{3}$, compared with a mean of 3,100 sherds $/ \mathrm{m}^{3}$ in the ritual dumps; for obsidian, the corresponding figures are 43 pieces $/ \mathrm{m}^{3}$ in middens compared with 100 pieces $/ \mathrm{m}^{3}$ in the dumps. For a limited sample of excavated lots (selected to illustrate sherd size; see later), the corresponding densities are 3,130 sherds $/ \mathrm{m}^{3}$ in the ritual dump, Unit 224, and 1,700 sherds $/ \mathrm{m}^{3}$ in a sample of 52 midden lots (Table 4). The second distinctive characteristic is that the sherds in the ritual dumps are larger than those in middens (Table 4).

Third, it was possible to reassemble numerous whole or partial ceramic vessels from the ritual dumps, and sherd mends often cut across the dump deposit both vertically and horizontally. This situation was not found in the middens, whose ceramic remains were highly fragmented and could never be reassembled into whole, or even partial, vessels. Limited quantitative support for this suggestion is provided by the data in Table 5, which compares ratios of sherd counts to minimal vessel counts in the Unit 224 ritual dump and the nearest extensively excavated house, Unit 201. Minimum numbers of vessels were estimated by a procedure based on rim counts (described in Smith 1992). The lower ratios for the ritual dump indicate that there were fewer sherds per vessel in the ritual dump - that is, the broken vessels are less highly fragmented than in middens. ${ }^{9}$

A final observation about the ceramics of the ritual dumps is that they always dated to the same ceramic phase as the middens of the houses in their patio group. These characteristics of the Cuexcomate ritual dumps and their contents suggest that they were

\footnotetext{
${ }^{9}$ The ratios in Table 5 substantially underestimate the differences between the two deposits due to data-recording decisions in the laboratory. When sherds were glued together to form complete or partial vessel, they were counted as a single sherd in the sherd counts. If the original counts of unmended sherds were available, the ratios for Unit 224 would be far lower than indicated in Table 5.
} 


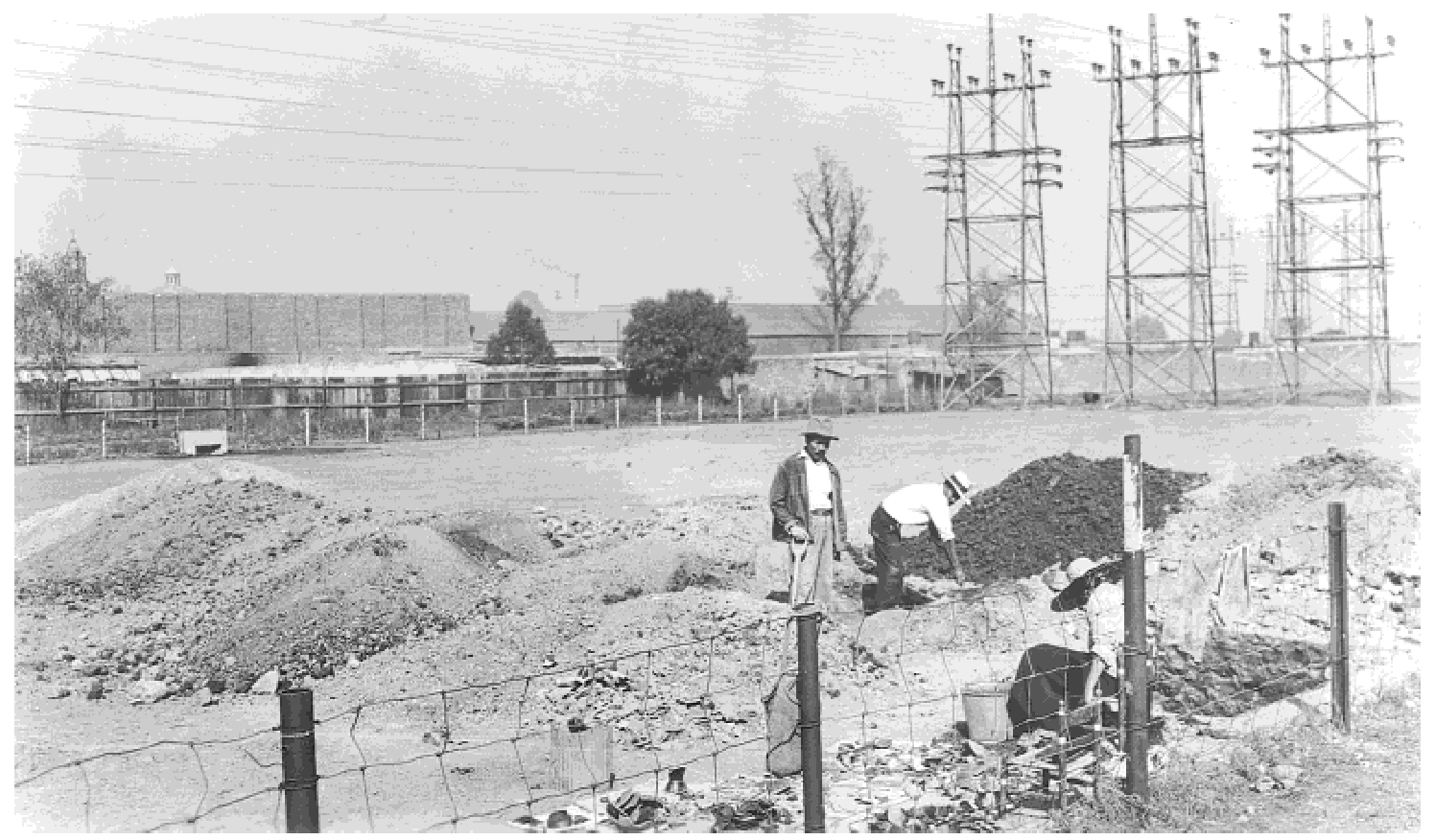

Figure 6. Photo of excavations at Nonoalco (note the church cupola at far left).

formed in single episodes in which large numbers of domestic items were discarded into special pits, then covered with a layer of rocks.

The ceramic inventories of the dumps are quite similar to domestic inventories (Table 3). All of the major domestic functional and form classes are present in the ritual dumps, and most of the specific types of local and imported painted serving ware characteristic of domestic inventories (Smith 2002) are also present in the ritual dumps. Most of the quantitative differences between the dumps and their nearby domestic deposits are relatively minor, and where significant differences exist, they are not consistent in all three cases. For example, the dumps in Patio Groups 3 and 9

\section{PATIO GROUP 3}

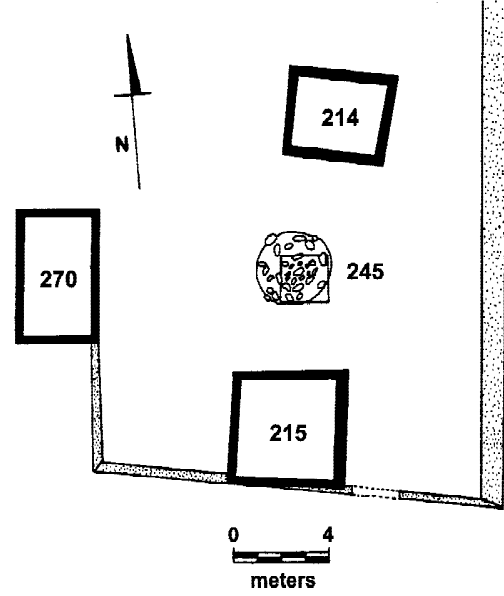

KEY:

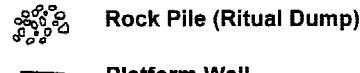

Platform Wall

224
PATIO GROUP 10

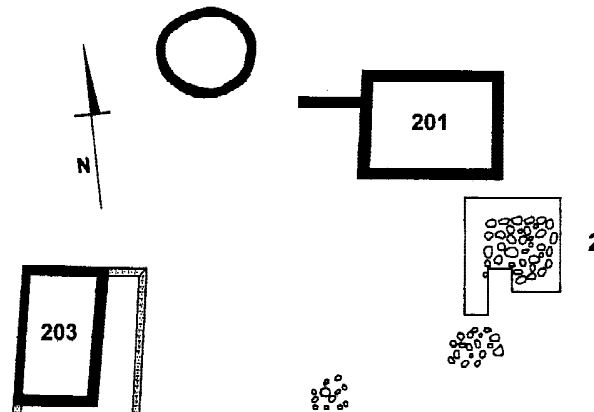

224

Figure 7. Plans of Patio Groups 3 and 10 at Cuexcomate showing the locations of ritual dumps and the excavated areas of two dumps, Units 245 and 224 . 


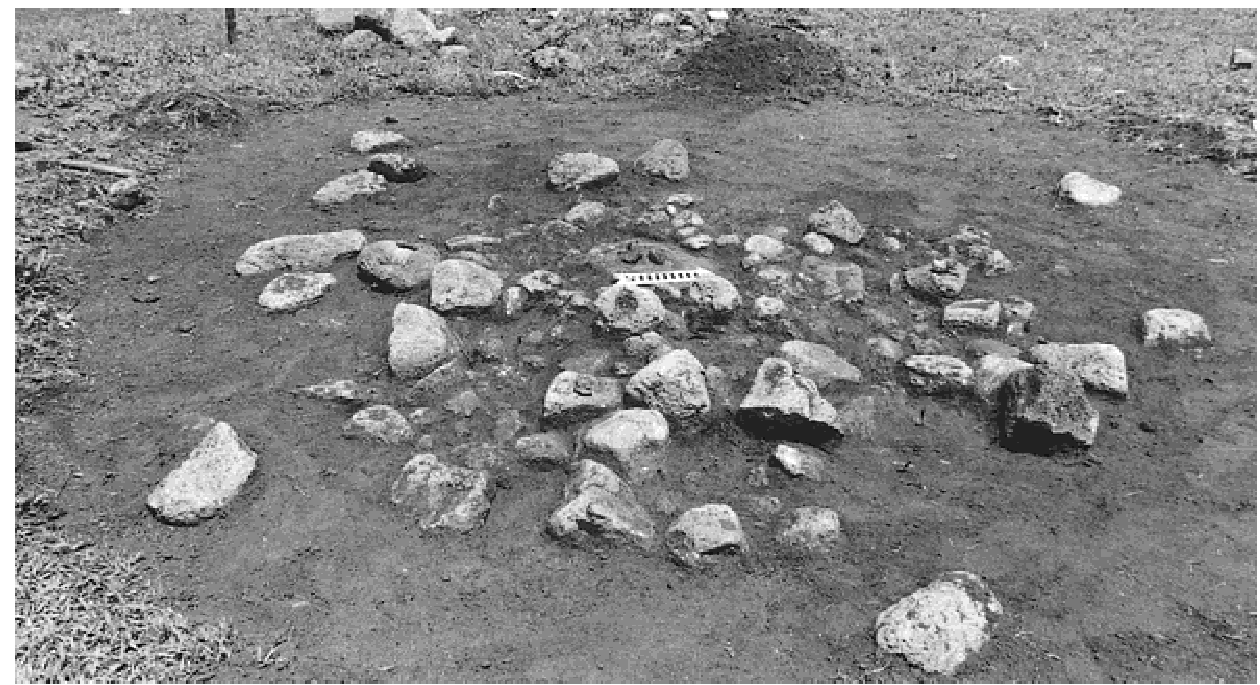

Figure 8. Photo of ritual dump at Cuexcomate (Unit 245) prior to excavation.

have more censers and other ritual items than the houses do, but in Patio Group 10, the frequencies of ritual items are not very different between the dump and the houses.

One difference between the ceramics of the Unit 224 dump and domestic ceramics at Cuexcomate is the presence of several unique vessels in the ritual dump. These include a globular jar with a pedestal base and an oval opening in the side of the jar (perhaps an unusual censer?) and a vessel with a flat, roughened base similar to a comal, but with tall sloping walls like a basin. Either these unusual vessels were deliberately deposited only in ritual dumps,
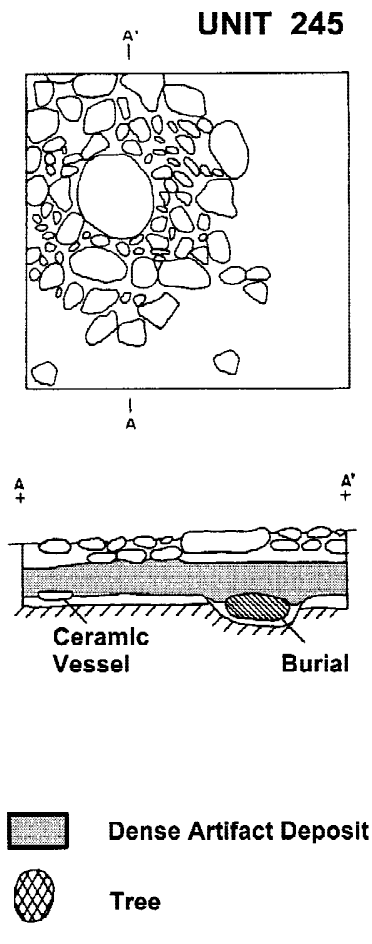

די

Limit of Excavation
Dense Artifact Deposit

Tree

0

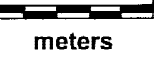

$i^{\prime}$

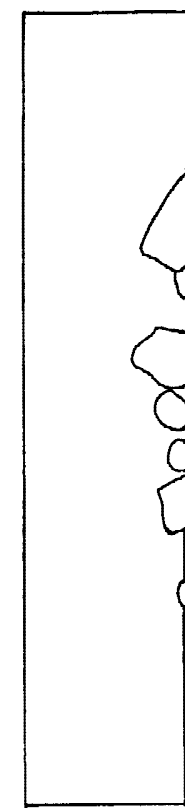

$+$
UNIT 224

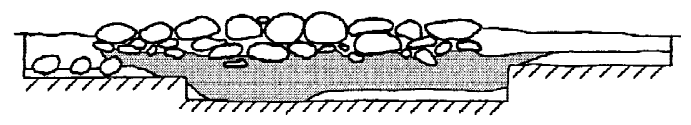

Figure 9. Plan and profile of ritual dumps at Cuexcomate (Units 224 and 225). 
Table 4. Ceramic density and sherd size in ritual dumps and middens at Cuexcomate

\begin{tabular}{lrrrrr}
\hline \hline & \multicolumn{2}{c}{ Ritual Dump: } & & \multicolumn{2}{c}{ Middens: } \\
\cline { 2 - 3 } \cline { 5 - 6 } Measure & Mean & SD & & Mean & SD \\
\hline \multirow{2}{*}{ Ceramic density } & $3,129.8$ & 948.1 & & $1,702.4$ & $1,367.1$ \\
Bowl sherd size & 6.4 & 2.1 & & 4 & 1.1 \\
Jar sherd size & 14.4 & 6.3 & & 7.6 & 2.5 \\
\hline \hline
\end{tabular}

Notes: The ritual dump sample consists of all 13 excavated levels in unit 224 . The midden sample consists of 52 Late Cuauhnahuac excavated levels with more than 100 sherds. SD, standard deviation.

or such vessel forms may have been more widely distributed at Cuexcomate but have not been identified due to the fragmentary and eroded condition of the sherds in the middens.

\section{The Volador Deposit from Tenochtitlan}

In 1936-1937, Eduardo Noguera excavated an offering of approximately 1,000 ceramic vessels in Mexico City that has been interpreted by some as a New Fire deposit. The vessels had been placed inside a large stone platform located at the southeastern corner of the Zócalo of Mexico City in what had been known as the Plaza del Volador, presumably the pre-Hispanic location of the Aztec volador ceremony. In the volador ceremony, several individuals, whose feet were tied to long ropes wrapped around a tall pole, leapt off the pole to "fly" in circles as the ropes unwound. The ceramic vessels and a stone sculpture were found in a stone-lined chamber. The excavation was never published in detail. In his report to the Mexican government (reproduced in Solís Olguín and Morales Gómez 1991:79-80), Noguera suggested that the offerings related to the volador ceremony. He later published a brief article (Noguera 1968) attributing the offering to the New Fire Ceremony. The excavation was carried out soon after Vaillant had excavated at Chiconautla and Nonoalco, and Vaillant and his Mexican colleagues (including Noguera) had been discussing the identification of the deposits at those (and perhaps other) sites as New Fire remains.

Noguera's interpretation of the volador deposit as the remains of a New Fire Ceremony has been accepted by most authors (e.g., López Luján 1994:12; Solís Olguín and Morales Gómez 1991; Vega Sosa 1975:8), but there is little support for this speculation. We will show later that the ceramics from this deposit do not at all resemble the remains from the ritual dumps described

Table 5. Ratios of sherds to minimal vessel counts at Cuexcomate

\begin{tabular}{lcc}
\hline \hline Category & $\begin{array}{c}\text { Ritual Dump } \\
\text { (Unit 224) }\end{array}$ & $\begin{array}{c}\text { Midden } \\
\text { (Unit 201) }\end{array}$ \\
\hline Bowls & 7 & 10.8 \\
Jars & 34.4 & 48.4 \\
Comals & 18.7 & 30.7 \\
Total ceramics & 13.3 & 17.3 \\
\hline \hline
\end{tabular}

earlier. In a recent paper, Smith et al. (2002) suggest that, instead, the volador deposit contains the remains of elite feasting activities, with no necessary connection to the New Fire Ceremony. Most of the volador ceramics are now stored in the $\mathrm{Mu}$ seo Nacional de Antropología e Historia; photos of each of 897 vessels are published by Solís and Morales (1991). Additional vessels from the volador deposit, now in the collections of the Field Museum of Natural History in Chicago, are illustrated in McVicker (1992).

It is clear from Table 3 that the inventory of ceramic vessels in the Volador deposit is quite different from domestic deposits and from the ritual dumps described earlier. Although most of the vessels in that deposit are forms that also occur in domestic contexts, the frequencies are radically different. Sixty percent of the nearly 900 vessels illustrated in Solís and Morales (1991) are red biconical drinking cups, a form that occurs in domestic deposits and ritual dumps at a frequency of 1-2\% (Table 2); other abundant forms in the Volador collection are bi-level Black-on-Orange tripod dishes (16\%) and serving bowls painted with skulls and crossbones $(9 \%)$. The few kitchen vessels in that deposit are mostly molcajetes, or grater bowls.

\section{Discussion}

The ritual dumps described here contain the kinds of vessels expected from ethnohistoric descriptions of ritual dumps-basic domestic wares in similar proportions to household middens. The contents of the ritual dumps stand out in important ways, however. The condition of the ceramic assemblages in the dumps (large sherds, some whole vessels, and vessels that can be reassembled) and the manner in which the deposits were created (one-time events that produced dense and unstratified contexts) suggest that they are not middens. The locations of the Cuexcomate dumps within patio groups suggest that the activities that created these features involved the inhabitants of those groups. The fact that only five of 25 patio groups at the site had ritual dumps might be explained either by variation in ritual practices within the community or by specialization in ritual activities by the inhabitants of some patio groups.

The dump at Chiconautla's South House was a much larger deposit (in terms of numbers of artifacts), suggesting that this deposit may pertain to a larger group than the 15-20 members of the Cuexcomate patio groups. This feature may have been created as part of a public event-or, at least, an event in which members of the community other than the immediate residents of the house participated. The abundance of ash Vaillant found in the deposit suggests another parallel between public state rituals and household rituals: the importance of sweeping, and of keeping and renewing fires. Possibly, the ash from many household hearths was ritually swept and dumped into the deposit.

\section{Can the Ritual Dumps Be Used for Dating?}

Although the majority of Aztec Black-on-Orange ceramics in the dumps date to the Late Aztec period (after A.D. 1350), this period includes four New Fire dates: A.D. 1351, 1403, 1455, 1507. In western Morelos this interval has been divided into two phasesEarly Cuauhnahuac and Late Cuauhnahuac (Smith and Doershuk 1991) - each of which includes two New Fire dates. One ritual dump at Cuexcomate produced a radiocarbon sample whose 2-sigma range (A.D. 1397-1486) includes the New Fire dates A.D. 1403 and 1455 (sample no. SMU-2363, carbonized wood; see 


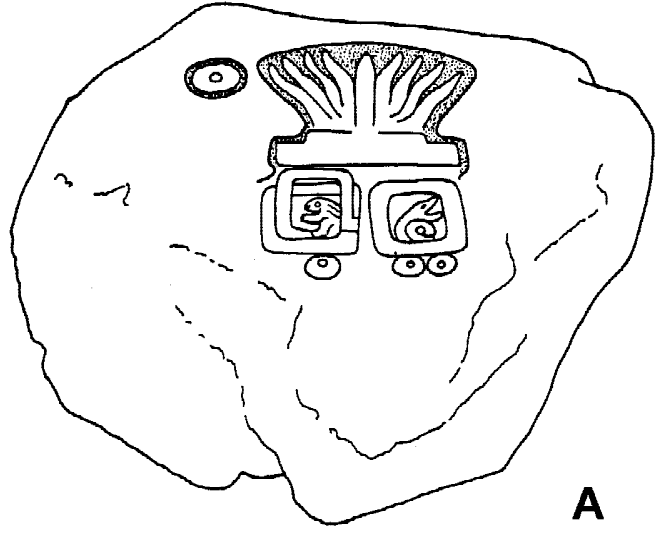

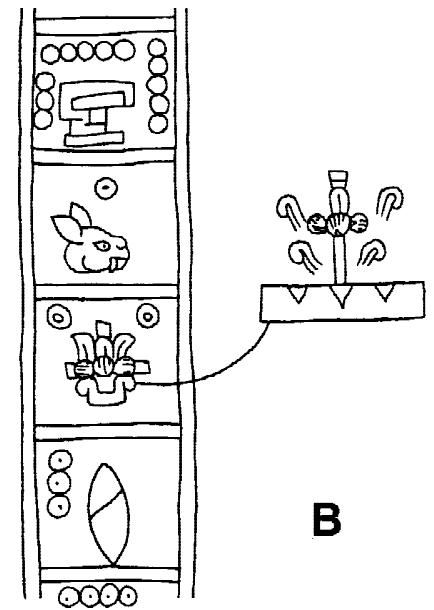

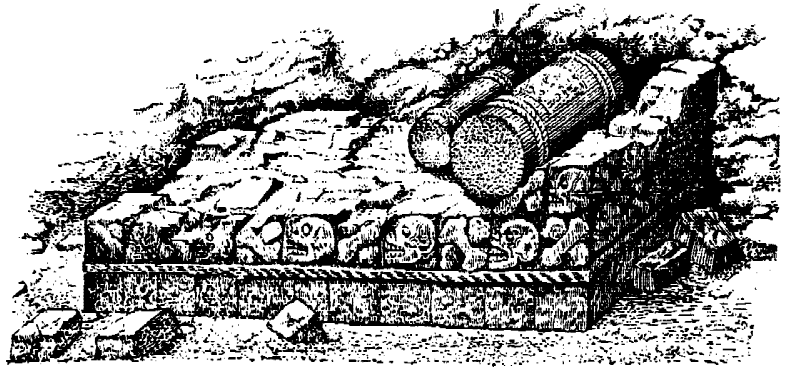

Figure 10. Iconographic depictions of the New Fire Ceremony. (A) The earliest known New Fire, from Xochicalco (after Sáenz 1967:12). This piece is designated No. B1 in the catalog of Smith and Hirth (2000). (B) The final Mexica New Fire Ceremony in the year 2 Reed (A.D. 1507), during the reign of Motecuhzoma Xocoyotzin (from the Codex Mendoza, after Berdan and Anawalt 1992:Volume 4, Folio 15v). (C) Stone sculptural representations of the 52-year bundles, Xiuhmolpilli, excavated at the Templo Mayor (after Batres 1979 [1905]:153).
Smith and Doershuk [1991]). Based on the presence of some Early Cuauhnahuac ceramics in this Late Cuauhnahuac deposit, Smith suggested that the New Fire date of A.D. 1455 (shortly after the transition from Early to Late Cuauhanhuac) is more likely than the next such date, A.D. 1507. Vaillant suggested a date of A.D. 1507 for the dump at Nonoalco. Without an alternative method of chronological refinement, ritual dumps cannot be used for dating; however, the seven examples we have discussed all fall within the Late Aztec Period, suggesting that this kind of celebration took place simultaneously in different parts of the Aztec empire.

\section{AZTEC RELIGION, IDEOLOGY, AND CULTURAL EVOLUTION}

The Aztec New Fire Ceremony provides a rare opportunity to integrate our knowledge of Aztec state and domestic ritual, as well as to compare ethnohistoric and archaeological data. This is one of the few examples outside of the Templo Mayor where specific archaeological deposits can be related with confidence to ritual activities described in the ethnohistoric sources.

\section{History of the Aztec New Fire Ceremony}

The iconographic symbol of the New Fire Ceremony was a fire drill with flames. The earliest clear-cut example of this occurs on a stone relief from Xochicalco, Morelos (Figure 10A), in which the symbol is accompanied by calendrical glyphs 1 Rabbit (a year designation) and 2 Snake (a probable day name). This stone is carved in the Xochicalco sculptural style of A.D. 650-900 (Hirth 2000), and César Sáenz (1967) considers it a commemoration of the first New Fire Ceremony. Emily Umberger (1987a, 1996) has shown that Mexica artists deliberately imitated the sculptural styles of Xochicalco, Tula, and Teotihuacan. She notes that in Tenochtitlan, "another sculpture with a date surrounded by a Xochicalcostyle frame was carved in connection with the New Fire Ceremony of 1507, and the archaizing style recalls the site where the Tenochca considered that their calendar was initiated and the first new fire was lighted" (Umberger 1996:94).

The method of historical transmission of the New Fire Ceremony from Xochicalco to Tenochtitlan is not clear. Nine New Fire Ceremonies are noted in the Aztec historical sources; the Mapa Sigüenza, for example, mentions eight New Fires (Boone 2000:166-173). These are listed in Table 6, which we take from

Table 6. New Fire Ceremonies in Mexica historical accounts

\begin{tabular}{llll}
\hline \hline Number & Year & Year & \multicolumn{1}{c}{ Location } \\
\hline 1 & 1 Rabbit & 1090 & Teocolhuacan \\
2 & 1 Rabbit & 1142 & Coatepec (Tollan) \\
3 & 1 Rabbit & 1194 & Huitzcol Apazco \\
4 & 1 Rabbit & 1246 & Tecpayocan \\
5 & 1 Rabbit & 1298 & Chapultepec \\
6 & 2 Reed & 1351 & Tenochtitlan \\
7 & 2 Reed & 1403 & Tenochtitlan \\
8 & 2 Reed & 1455 & Huixachtecatl \\
9 & 2 Reed & 1507 & Huixachtecatl \\
\hline \hline
\end{tabular}

Source: Tena (1987:98) 
Tena (1987:98), who provides citations to the primary sources that mention each event (see also Boone 2000:223-224). At least two centuries separate the Xochicalco New Fire and the earliest Mexica example. The interval between these dates, the Early Postclassic period, was the time of Toltec civilization. Sáenz (1967:13) and Tena (1987:92) suggest that the Mexica must have adopted the New Fire Ceremony from the Toltecs. In spite of some speculation about the possible presence of the New Fire Ceremony at Toltec-period Tula (Coggins 1987, 1989), we know of no direct iconographic or other evidence for the ceremony at Tula (de la Fuente et al. 1988). ${ }^{10}$

Instead of assuming that the Mexica of Tenochtitlan adopted the New Fire Ceremony from a specific ancient city (Xochicalco or Tula), it may be more fruitful to suggest that the practice was widespread in Postclassic northern Mesoamerica, perhaps employed by most peoples. The Mexica adopted this practice and used it for their own imperial ends. ${ }^{11}$ There are many examples of new fire being drilled in the Mixtec codices (Boone 2000:94-160) and depictions of the drilling of New Fire in the Historia ToltecaChichimeca (e.g., Boone 2000:180-181; Kirchhoff et al. 1976: folios $32 \mathrm{v}-33 \mathrm{r}$ ) shows the presence of the practice among the eastern Nahua peoples of southern Puebla. To the Mixtecs, the New Fire Ceremony had a meaning very different from that of the Aztecs. As depicted in the Mixtec codices and lienzos, the new fire was drilled by priests or nobles as one of the rituals of the foundation of a new town (Boone 2000:94-160; Furst 1990). Like the Aztec version, the Mixtec New Fire Ceremony was a rite of renewal and beginning, but the focus was on the start of a new town and polity, not a new cosmic era.

According to the reconstructions by Tena (1987) and Umberger (1987b), the Mexica moved the year of celebration from 1 Rabbit (1350) to 2 Reed (1351) for their sixth New Fire Ceremony, and 2 Reed became the normal date for these events through the Spanish Conquest. ${ }^{12}$ The Mexica historical sources indicate that some New

${ }^{10}$ Several authors have argued for the presence of the New Fire Ceremony at other prominent Mesoamerican sites based on tenuous iconographic evidence. Von Winning (1979), for example, suggests that it was present at Teotihuacan, and his argument has been seconded by Langley (1997). Coggins $(1987,1989)$ argues for the New Fire Ceremony at Chichen Itza as well as at Teotihuacan, Kaminaljuyu, Becan, Zaculeu, and Tula. Coggins bases her argument on the presence of isolated elements assumed to be part of the ritual complex of the New Fire Ceremony, including the bundle of canes, fire drill, the number seven, and the Kan cross and pyrite mirrors (1987:446).

In contrast to these isolated elements without context, the depictions in the Aztec and Mixtec codices and lienzos show either the New Fire element linked spatially to date glyphs or individuals engaged in lighting a new fire. We do not view the isolated iconographic depictions at other sites as strong evidence for the practice of the New Fire Ceremony at these sites. Furst (1992) takes a very broad perspective and compares the Aztec New Fire Ceremony to numerous renewal rituals involving fire found among native cultures throughout the New World. These comparisons are interesting, but we do not consider them useful for understanding the history or context of the Aztec New Fire Ceremony. There is no evidence for New Fire Ceremonies, or other 52-year celebrations, in Classic Maya inscriptions or in Postclassic Maya codices (John Justeson, personal communication 2001).

${ }^{11}$ Hassig (2001:118) suggests that the New Fire Ceremony was "observed only in political centers which controlled the calendar." According to Hassig, Tenochtitlan was the only polity in the Basin of Mexico to celebrate the New Fire Ceremony, and outside the Basin, Tlaxcalla also held New Fire celebrations (Hassig 2001:97).

${ }^{12}$ This interpretation has been questioned by Edward Calnek, who suggests that "there is little (or no) acceptable documentary evidence for the shift" (letter to Michael Smith, October 28, 2000, in the possession of Michael Smith).
Fire Celebrations were carried out as many as several years after the target date, due to the unstable situation of the Mexica in their early centuries in the Basin of Mexico (see Tena 1987:91-93). According to the Anales de Tlatelolco (1948:18), once the Mexica had founded Tenochtitlan in A.D. 1325 (2 House), they celebrated an impressive New Fire Ceremony in Chapultepec. This may have been done to erase the memory of the two former ceremonies, each of which had to be delayed because of humiliating military defeats in the years 1 Rabbit (1246 and 1298). At this point in their history, the Mexica-like the Mixtecs or eastern Nahua peoplesmay have been using the New Fire Ceremony as a ritual of foundation. By the mid-fifteenth century, however, the New Fire Ceremony at Tenochtitlan had taken on the imperial associations noted earlier.

Even after A.D. 1428 and the formation of the Triple Alliance, the date used by the Mexica of Tenochtitlan to mark the New Fire Ceremony was not necessarily the same date used by other ethnic groups. The Chichimec used 9 Tecpatl; the Acolhua used 1 Tecpatl; the Totomihuaque used 7 Acatl; and the Tepaneca, Culhuaque, and Mexica used 2 Acatl (López Austin 1973:99; Marcus 1992:117-118). In fact, Brundage (1985:36) suggests that in 1507, the imperial leaders decided to celebrate the New Fire in the month of Panquetzaliztli (late November-early December), associated with Quetzalcoatl instead of Izcalli (late January-mid-February) because of that god's association with the origin of the Fifth Sun (Figure 10b).

In an alternative to Tena's and Umberger's interpretation, Hassig (2001:38-47, 114), follows a suggestion in the Codex Telleriano-Remensis (Quiñones Keber 1995:Folio 41v) that the change from 1 Rabbit to 2 Reed was done for the New Fire Ceremony of 1507 :

In this year [1 Rabbit, 1506] they were to bind the years according to their count, and because it was always a difficult year for them, Motecuhzoma changed it to two reeds [i.e., the year 2 Reed, 1507] [Quiñones Keber 1995:274].

The Codex goes on to state that "in this year [2 Reed, 1507] they finished the church of the new fire" on top of Mount Huixachtlan (Quiñones Keber 1995:274). Hassig (2001:47) takes this to mean that the state ritual was moved at that time from the Templo Mayor to Mount Huixachtlan, although this is not stated in the Codex or other sources. He suggests that scribes later went back and retrospectively changed the dates of earlier New Fire celebrations in the historical records to 2 Reed in order to give the Mexica ceremony greater legitimacy. Regardless of exactly when the New Fire date was changed, and regardless of when (or whether) the lighting of the fire was moved from Tenochtitlan to Mount Huixachtlan, the sources are clear that by 1507 the ritual had become a major political event for the Mexica state. Provincial peoples were well aware of the New Fire Ceremony by 1507; the Xicotepec Codex from the Sierra Norte de Puebla, for example, mentions the 1507 New Fire celebration but not the 1455 event, even though its span of historical coverage includes both dates (Stresser-Péan 1995).

\section{Top-Down and Bottom-Up Perspectives}

Mexica state ideology, as expressed through the works of the chroniclers, clearly emphasized the imperial nature of the New Fire Ceremony. The new fire, controlled by the Mexica king, was distributed from Tenochtitlan throughout the empire, symbolizing the subordination of provincial peoples to the capital (D. Carrasco 1999:96-114). As a way to legitimize their imperial rule, the Mex- 
ica copied specific sculptural pieces, themes, and styles from Teotihuacan, Xochicalco, and Tula (Umberger 1987a, 1996). The fact that Mexica sculptors, as part of this imperial artistic program, deliberately made visual reference to the ancient Xochicalco New Fire carving (Umberger 1996:94) reinforces the imperial associations of the ceremony. ${ }^{13}$ Carved-stone year bundles were buried in various deposits in and around the Templo Mayor (Figure 10c). From this top-down perspective, one might be tempted to interpret the presence of New Fire ritual dumps at provincial sites as evidence for the penetration of imperial ideology down to the provincial household level. As an alternative, however, we suggest that a bottom-up perspective- that the Mexica appropriated a more widespread popular ritual for imperial purposesbetter fits the archaeological and ethnohistoric data.

One of the characteristics of Aztec imperialism is that the empire made little or no effort to impose Aztec religion on conquered peoples. Instead, Aztec religion was actively inclusive, incorporating numerous gods and rituals from conquered peoples. Idols of foreign gods were brought to Tenochtitlan and displayed in a special temple. Even state-linked rituals such as human sacrifice, central to Aztec imperial ideology (D. Carrasco 1999), were ancient Mesoamerican practices going back at least as far as Teotihuacan (Cabrera Castro et al. 1991; Taube 1992) and the Classic Maya (Taube 1988; Welsh 1988). Human sacrifice is documented for the Middle Postclassic (pre-Mexica) Nahua cultures of Morelos (Lagunas R. and Sánchez 1972), showing that its use among the Nahua peoples long predated the Aztec empire.

The Xochicalco inscription (Figure 10a) shows the antiquity of the New Fire Ceremony (or, at least, the iconographic expression of that ceremony) in central Mexico. Cuexcomate is located only $3 \mathrm{~km}$ from Xochicalco, and structures at the Postclassic site incorporate carved stones that were almost certainly looted from Xochicalco (Smith 1992:177). Thus, it is entirely possible that the New Fire Ceremony was a local tradition in western Morelos, maintained through the four or five centuries that separated the fall of Xochicalco from the founding of Cuexcomate; unfortunately, the lack of Early Postclassic excavations in western Morelos, and the small number of excavated Middle Postclassic contexts, prevent the evaluation of this suggestion. One of the six dated ritual dumps at Cuexcomate pertains to the Early Cuauhnahuac period. Because this period predates the conquest of Morelos by the Aztec empire, it is difficult to argue that the Late Cuauhnahuac New Fire celebrations were somehow imposed by the Aztec empire.

Taking a broader perspective, we know that some rituals associated with New Year ceremonies had a wide distribution in Mesoamerica. For example, the general pattern of Postclassic Yucatec Maya New Year (Uayeb) ceremonies included the manufacture of pottery idols representing the god of the coming year (and sometimes other deities) that were paraded to different parts of town and presided over ceremonies at the residence of a lord chosen to host feasts and ceremonies. At some celebrations, ceramic censers were discarded in deposits outside of towns, and people started over with new censers (Landa 1941). On the first day of the New Year, daily household articles were replaced during a solemn ren-

${ }^{13}$ Another example of the transformation of existing myth and ritual by the Mexica to promote their imperial ideology is provided by Graulich (1997:76-79), who argues that the Mexica added a fifth creation era, or "sun," to the older Mesoamerican mythological theme of four previous suns. He suggests, "When the Mexica took over and reestablished a great empire in Mexico, they claimed that their arrival was the beginning of the Fifth Sun" (Graulich 1997:79). ovation ceremony, and houses were swept clean; however, there is no evidence that the Maya assigned any special significance to the 52-year cycle (Sharer 1994:551). Excavations at Santa Rita Corozal, Belize, have uncovered caches of ceramic figurines in elite residences or platforms that never appear in other deposits, and the excavator suggests that the figurines and associated paraphernalia were made especially to be deposited during New Year ceremonies (Chase 1985, 1986).

The New Fire Ceremony expressed widespread Mesoamerican beliefs independent of an imperial ideology: the notion of a "living" fire that had to be carefully tended; the ability of inanimate objects to be receptacles for divine essences; and the conception of time as cyclical, including the belief that periods of renewal are dangerous. The behavior associated with the creation of artifact dumps-ritually rekindling the hearth fire, sweeping and removing ash, throwing out and purposely smashing household goods and figurines, and communal feasting and drinking-was not dictated by imperial ideology.

It is likely that the timing of New Fire celebrations, or similar rituals of renewal, was traditionally the prerogative of local rulers. City-states in the Basin of Mexico, before the institutionalization of Tenochtitlan hegemony, had their own priests and probably kept their own calendars (and presumably New Fire dates), which would have been a critical way of maintaining local history and identity (Marcus 1992:118; see Hassig 2001:97, 118, for a dissenting view). The Aztec imperial order, however, created fantastic New Year ceremonies, like the one described on Mount Huixachtlan, on their own auspicious dates that far outshone any other city-state's New Fire Ceremony.

We suggest that the existence of the New Fire Ceremony at diverse settlements-Tenochtitlan, Chiconautla, Nonoalco, and Cuexcomate-should not be seen simply as a case of imperial domination through the imposition of religious rituals on subject peoples. When viewed from a bottom-up perspective on Aztec cultural evolution, many of the underlying behaviors and beliefs associated with the New Fire Ceremony, and the presence of the ceremony at four diverse locations, can be seen as a manifestation of the cultural unity that linked the Aztec peoples of the Basin of Mexico, Morelos, and probably other nearby areas, as well (Smith 1996). This Aztec cultural unity was the foundation for the Colonialperiod Nahua culture of central Mexico (Lockhart 1992). Local elites may have actively emphasized diversity in the timing and expression of religious behaviors and beliefs as a means of maintaining local political and ethnic identities. By placing household rituals such as the distribution of fire to houses and temples from Mount Huixachtlan in a hierarchical political framework, however, the emperor cross-cut city-states' boundaries, undermined the political power of local elites, and co-opted religious ideology for a program of imperial legitimization and glorification.

The imperial use of the New Fire Ceremony can be summarized as follows: The Mexica, like other Nahuatl and Mixtec peoples, engaged in a ritual of lighting a new fire, perhaps combining a symbol of foundation with a celebration of the completion of a 52 -year cycle. Once they had forged an empire, however, the Mexica rulers gave the ritual the full trappings of a cosmic imperial celebration, including performance on top of a mountain, human sacrifice, participation of the emperor, and ceremonial distribution of the fire throughout the empire, all within a mythological framework that connected the empire to the calendric cycles of the cosmos. Exclusive attention to the propagandistic written sources from Tenochtitlan might suggest that this was an imperial ritual imposed on the populace of the hinterland, but our consideration 
of the archaeological remains of local New Fire celebrations shows that such a perspective is misleading. The forms of Aztec ritual were worked out through a dialectic between traditional local and household practices, on one hand, and innovative imperial poli- cies, on the other. The combination of ethnohistoric and archaeological data on the New Fire Ceremony helps us see this dialectic more clearly and thus contributes to a more comprehensive model of Aztec religion and society.

\section{RESUMEN}

La ceremonia del año nuevo llamado Xiuhtlalpilli en Nahuatl ocurrió cada 52 años y marcó un nuevo siglo en el calendario azteca. La ceremonia del Nuevo Fuego es una de las pocas ceremonias aztecas documentadas en la arqueología y en la historia. Los cronistas españoles describieron dicha ceremonia como una celebración imperial que servía para renovar el tiempo cósmico. Al nivel local, los celebrantes demarcaron el evento renovando sus enseres domésticos. El arqueólogo George C. Vaillant propuso que ciertos basureros de artefactos en sitios aztecas constituían evidencia de la renovación de los enseres domésticos documentados en las celebraciones locales. Describimos dos basureros de artefactos domésticos excavados por Vaillant, uno en Chiconautla y uno en Nonoalco, hasta ahora no descritos en la literatura publicada y un basurero de artefactos domésticos excavado por Smith en Cuexcomate, Morelos. Demostramos que el contexto y el contenido de los basureros apoyan el hipótesis de Vaillant. Nuestros datos sugieren que la ceremonia del Nuevo Fuego fue un ritual de mucha antigüedad y muy extenso que en el México postclásico fue apropiado por el imperio azteca como parte de su programa de dominación política y legitimación ideológica.

\section{ACKNOWLEDGMENTS}

We thank Elizabeth Boone, Edward Calnek, Joyce Marcus, Donald McVicker, and two anonymous referees for comments on an earlier draft of this paper. Elson thanks Charles S. Spencer of the Department of Anthropology, American Museum of Natural History, for permission and

\section{REFERENCES}

Anales de Tlatelolco

1948 Anales de Tlatelolco: Unos Anales Históricos de la Nación Mexicana, y Códice de Tlatelolco. Edited by Heinrich Berlin. Antiguo Librería Robredo, Mexico City.

Batres, Leopoldo

1979 (1905) Exploraciones arqueológicas en la Calle de las Escalerillas. In Trabajos Arqueológicos en el Centro de la Ciudad de México, edited by Eduardo Matos Moctezuma, pp. 111-170. Instituto Nacional de Antropología e Historia, Mexico City.

Berdan, Frances F., and Patricia R. Anawalt (editors)

1992 The Codex Mendoza. 4 vols. University of California Press, Berkeley.

Berdan, Frances F., Richard E. Blanton, Elizabeth H. Boone, Mary G.

Hodge, Michael E. Smith, and Emily Umberger

1996 Aztec Imperial Strategies. Dumbarton Oaks, Washington, DC.

Boone, Elizabeth $\mathrm{H}$

2000 Stories in Red and Black: Pictorial Histories of the Aztecs and Mixtecs. University of Texas Press, Austin.

Boone, Elizabeth H. (editor)

1987 The Aztec Templo Mayor. Dumbarton Oaks, Washington, DC.

Broda, Johanna

1982 La fiesta azteca del Fuego Nuevo y el culto de las Pléyades. In Time and Space in Ancient American Cosmovision, edited by Franz Tichy, pp. 129-157. Lateinamerican Studien Vol. 10. Universitat Erlangen-Nurnbery, Munich.

Broda, Johanna, Davíd Carrasco, and Eduardo Matos Moctezuma

1987 The Great Temple of Tenochtitlan: Center and Periphery in the Aztec World. University of California Press, Berkeley.

Brumfiel, Elizabeth M.

1996 Figurines and the Aztec State: Testing the Effectiveness of Ideological Domination. In Gender and Archaeology, edited by Rita P. Wright, pp. 143-166. University of Pennsylvania Press, Philadelphia.

Brundage, Burr C.

1985 The Jade Steps: A Ritual Life of the Aztecs. University of Utah Press, Salt Lake City.

Cabrera Castro, Rubén, Saburo Sugiyama, and George L. Cowgill

1991 The Templo de Quetzalcoatl Project at Teotihuacan: A Preliminary Report. Ancient Mesoamerica 2:77-92.

Calnek, Edward E.

1976 The Internal Structure of Tenochtitlan. In The Valley of Mexico: Studies of Pre-Hispanic Ecology and Society, edited by Eric R. Wolf, pp. 287-302. University of New Mexico Press, Albuquerque. encouragement in the study of George Vaillant's archaeological collections at the museum. Smith's fieldwork at Cuexcomate was supported by the National Science Foundation and Loyola University of Chicago.

Carrasco, Davíd

1991 To Change Place: Aztec Ceremonial Landscapes. University Press of Colorado, Boulder.

1999 City of Sacrifice: The Aztec Empire and the Role of Violence in Civilization. Beacon Press, Boston.

Carrasco, Pedro

1999 The Tenochca Empire of Ancient Mexico: The Triple Alliance of Tenochtitlan, Tetzcoco, and Tlacopan. University of Oklahoma Press, Norman.

Caso, Alfonso

1939 La correlación de los años Azteca y Cristiano. Revista Mexicana de Estudios Antropológicos 3:11-45.

1967 Los calendarios prehispánicos. Instituto de Investigaciones Históricas, Universidad Nacional Autónoma de México, Mexico City.

Chase, Diane Z.

1985 Ganned but Not Forgotten: Late Postclassic Archaeology and Ritual at Santa Rita Corozal, Belize. In The Lowland Maya Postclassic, edited by Arlen F. Chase and Prudence M. Rice, pp. 104-125. University of Texas Press, Austin.

1986 Social and Political Organization in the Land of Cacao and Honey: Correlating the Archaeology and Ethnohistory of the Postclassic Lowland Maya. In Late Lowland Maya Civilization: Classic to Postclassic, edited by Jeremy A. Sabloff and E. Wyllys Andrews V, pp. 347378. University of New Mexico Press, Albuquerque.

Códice Tudela

1980 Códice Tudela, José Tudela de la Orden. 2 vols. Ediciones Cultura Hispanica, Madrid.

Coggins, Clemency Chase

1987 New Fire at Chichen Itza. In Memorias del Primer Coloquio Internacional de Mayistas, 5-10 de agosto de 1985, pp. 427-482. Universidad Nacional Autónoma de México, Mexico City.

1989 A New Sun at Chichen Itza. In World Archaeoastronomy: Selected Papers from the 2nd Oxford International Conference on Archaeoastronomy, Held at Merida, Yucatan, Mexico, 13-17 January 1986, edited by Anthony F. Aveni, pp. 260-275. Cambridge Universitiy Press, New York.

de la Fuente, Beatriz, Silvia Terjo, and Gutiérrez Solana

1988 Escultura en Piedra de Tula: Catálogo. Instituto de Investigaciones Estéticas, Universidad Nacional Autónoma de México, Mexico City. 
Durán, Fray Diego

1967 Historia de las Indias de Nueva España. Translated by Angel M. Garibay K. 2 vols. Porrúa, Mexico City.

Elson, Christina M.

1999 An Aztec Palace at Chiconautla, Mexico. Latin American Antiquity 10:151-167.

Franco C., José Luis

1949 Algunos problemas relativos a la cerámica Azteca. El México Antiguo 7:162-208.

Furst, Jill Leslie McKeever

1990 Rulership and Ritual: Myth and the Origin of Political Authority in Mixtec Pictorial Manuscripts. In Circumpacifica: Festschrift für Thomas S. Barthel, vol. 1, edited by Bruno Illius and Matthias Laubscher, pp. 123-141. Peter Lang, Frankfurt.

1992 Aztec New Fire Ritual: A World Renewal Rite. Journal of Latin American Lore 18:29-36.

Gómez de Orozco, F.

1945 Costumbres, fiestas, enterramientos y diversas formas de proceder de los indios de Nueva España. Tlalocan 2(1):38-63.

Graulich, Michel

1997 Myths of Ancient Mexico. Translated by Bernard R. Ortiz de Montellano and Thelma Ortiz de Montellano. University of Oklahoma Press, Norman.

1999 Fiestas de los pueblos indígenas: Ritos aztecas, las fiestas de las veintanas. Instituto Nacional Indígenista, Mexico City.

Griffin, James B., and Antonieta Espejo

1947 Alfarería correspondiente al último período de ocupación nahua del Valle de México. Memorias de la Academía Mexicana de la Historia 6(2):131-147.

1950 La alfafería del último período de ocupación del Valle de México, II: Culhuacan, Tenayuac, Tenochtitlan, y Tlatelolco. Memorias de la Academía Mexicana de la Historia 9(1):118-169.

Guilliem Arroyo, Salvador, Saturnino Vallejo Zamora, and Ángeles Medina Pérez

1998 Ofrenda en el Templo Mayor de México-Tlatelolco. Arqueología 19:101-118.

Hassig, Ross

2001 Time, History and Belief in Aztec and Colonial Mexico. University of Texas Press, Austin.

Hirth, Kenneth G. (editor)

2000 Archaeological Research at Xochicalco. Volume 1, Ancient Urbanism at Xochicalco: The Evolution and Organization of a PreHispanic Society. Volume 2, The Xochicalco Mapping Project. 2 vols. University of Utah Press, Salt Lake City.

Hodge, Mary G.

1984 Aztec City-States. Memoirs of the Museum of Anthropology Vol. 18. University of Michigan, Ann Arbor.

1998 Archaeological Views of Aztec Culture. Journal of Archaeological Research 6:197-238.

Hodge, Mary G., and Leah D. Minc

1990 The Spatial Patterning of Aztec Ceramics: Implications for Prehispanic Exchange Systems in the Valley of Mexico. Journal of Field Archaeology 17:415-437.

1991 Aztec-Period Ceramic Distribution and Exchange Systems. Report to the National Science Foundation, Washington, DC.

Kirchhoff, Paul, Lina Odena Güemes, and Luis Reyes García (editors)

1976 Historia tolteca-chichimeca. Instituto Nacional de Antropología e Historia, Mexico City.

Lagunas R., Zaid, and Carlos Serrano Sánchez

1972 Decapitación y desmembramiento corporal en Teopanzolco, Morelos. In Religión en Mesoamérica. XII Mesa Redonda, edited by Jaime Litvak King and Noemí Castillo Tejero, pp. 429-434. Sociedad Mexicana de Antropología, Mexico City.

Landa, Diego de

1941 Landa's Relación de las Cosas de Yucatan. Translated by Alfred M. Tozzer. Papers of the Peabody Museum of Archaeology and Ethnography Vol. 18. Harvard University, Cambridge.

Langley, James

1997 Teotihuacan Incensarios: The "V" Manta and Its Message. Teotihuacan Notes: Internet Journal for Teotihuacan Archaeoalogy and Iconography 1(3):1-11. Available from: http://archaeology/la.asu.edu/ teo/notes/JL/notes1_3.htm.

León-Portilla, Miguel

1963 Aztec Thought and Culture: A Study of the Ancient Náhuatl Mind. University of Oklahoma Press, Norman.
Lockhart, James

1992 The Nahuas After the Conquest: A Social and Cultural History of the Indians of Central Mexico, Sixteenth Through Eighteenth Centuries. Stanford University Press, Stanford, CA.

López Austin, Alfredo

1973 Hombre-Díos: Religión y política en el mundo Náhuatl. Universidad Nacional Autónoma de México, Mexico City.

1997 Tamoanchan, Tlalocan: Places of Mist. Translated by Bernard R. Ortiz de Montellano and Thelma Ortiz de Montellano. University Press of Colorado, Niwot.

López Luján, Leonardo

1994 The Offerings of the Templo Mayor of Tenochtitlan. Translated by Bernard R. Ortiz de Montellano and Thelma Ortiz de Montellano. University Press of Colorado, Niwot.

Marcus, Joyce

1992 Mesoamerican Writing Systems: Propaganda, Myth, and History in Four Ancient Civilizations. Princeton University Press, Princeton, NJ.

Marquina, Ignacio

1951 Arquitectura Prehispánica. Instituto Nacional de Antropología e Historia, Mexico City.

Matos Moctezuma, Eduardo

1988 The Great Temple of the Aztecs. Thames and Hudson, New York.

McVicker, Donald E.

1992 México: La Visión del Cosmos: Three Thousand Years of Creativity. Mexican Fine Arts Center Museum, Chicago.

Moedano, Hugo

1951 Ce Acatl igual Ome Acatl, como fin de Xiuhmolpilli. Revista Mexicana de Estudios Antropológicos 12:103-131.

Motolinía, Fray Toribio de Benavente

1951 Motolinía's History of the Indians of New Spain. Translated by Francis Borgia Steck. Academic of American Franciscan History, Washington, DC.

Nicholson, H.B.

1955 Native Historical Traditions of Nuclear America and the Problem of Their Archeological Correlation. American Anthropologist 57:594-613.

1971a Pre-Hispanic Central Mexican Historiography. In Investigaciones Contemporáneas Sobre Historia de México, pp. 38-81. El Colegio de México and University of Texas Press, Mexico City and Austin.

1971b Religion in Pre-Hispanic Central Mexico. In Archaeology of Northern Mesoamerica, Part 1, edited by Gordon F. Ekholm and Ignacio Bernal, pp. 395-446. Handbook of Middle American Indians, vol. 10. University of Texas Press, Austin.

Noguera, Eduardo

1968 Ceremonias del Fuego Nuevo. Cuadernos Americanos 158(3): 146-151.

Olmos Frese, Laura del

1999 Análisis de la ofrenda 98 del Templo Mayor de Tenochtitlan. Colección Científica, Vol. 384. Instituto Nacional de Antropología e Historia, Mexico City.

Parsons, Jeffrey R.

1966 The Aztec Ceramic Sequence in the Teotihuacan Valley, Mexico. 2 vols. Ph.D. dissertation, Department of Anthropology, University of Michigan, Ann Arbor.

Parsons, Jeffrey R., Elizabeth Brumfiel, and Mary Hodge

1996 Developmental Implications of Earlier Dates for Early Aztec in the Basin of Mexico. Ancient Mesoamerica 7:217-230.

Parsons, Mary $\mathrm{H}$.

1972 Aztec Figurines from the Teotihuacán Valley, Mexico. In Miscellaneous Studies in Mexican Prehistory, edited by Michael W. Spence, Jeffrey R. Parsons, and Mary H. Parsons, pp. 81-164. Anthropological Papers Vol. 49. Museum of Anthropology, University of Michigan, Ann Arbor.

Quiñones Keber, Eloise

1995 Codex Telleriano-Remensis: Ritual, Divination, and History in a Pictorial Aztec Manuscript. University of Texas Press, Austin.

Sáenz, César A.

1967 El Fuego Nuevo. Serie Historia, Vol. 18. Instituto Nacional de Antropología e Historia, Mexico City.

Sahagún, Fray Bernardino de

1950-1982 Florentine Codex, General History of the Things of New Spain. 12 books. Translated and edited by Arthur J.O. Anderson and Charles E. Dibble. School of American Research and University of Utah Press, Santa Fe and Salt Lake City. 
Sanders, William T., Jeffrey R. Parsons, and Robert S. Santley

1979 The Basin of Mexico: Ecological Processes in the Evolution of a Civilization. Academic Press, New York.

Sharer, Robert J.

1994 The Ancient Maya. 5th ed. Stanford University Press, Stanford, CA.

Smith, Michael E.

1992 Archaeological Research at Aztec-Period Rural Sites in Morelos, Mexico. Volume 1, Excavations and Architecture/Investigaciones Arqueológicas en Sitios Rurales de la Epoca Azteca en Morelos, Tomo 1, Excavaciones y Arquitectura. University of Pittsburgh Memoirs in Latin American Archaeology, Vol. 4. University of Pittsburgh, Pittsburgh.

1996 The Aztecs. Blackwell Publishers, Oxford.

2001a La cerámica Postclásica de Morelos. In La Producción Alfarera en el México Antiguo, edited by B. Leonor Merino Carrión and Angel García Cook,. Colección Científica. Instituto Nacional de Antropología e Historia, Mexico City.

2001b Domestic Ritual at Aztec Provincial Sites in Morelos. In Domestic Ritual in Ancient Mesoamerica, edited by Patricia Plunket. University of California at Los Angeles Institute of Archaeology, Los Angeles.

2002 Tlahuica Ceramics: The Aztec-Period Ceramics of Morelos, Mexico. IMS Monographs, Vol. 13. Institute for Mesoamerican Studies, State University of New York, Albany.

Smith, Michael E., and John F. Doershuk

1991 Late Postclassic Chronology in Western Morelos, Mexico. Latin American Antiquity 2:291-310.

Smith, Michael E., and Cynthia Heath-Smith

1994 Rural Economy in Late Postclassic Morelos: An Archaeological Study. In Economies and Polities in the Aztec Realm, edited by Mary G. Hodge and Michael E. Smith, pp. 349-376. Institute for Mesoamerican Studies, State University of New York, Albany.

Smith, Michael E., Jennifer Wharton, and Jan Marie Olson

2002 Aztec Feasts, Rituals, and Markets: Political Uses of Ceramic Vessels in a Commercial Economy. In Pots as Political Tools: The Culinary Equipment of Early Imperial States in Comparative Perspective, edited by Tamara Bray, in press.

Smith, Virginia, and Kenneth G. Hirth

2000 A Catalog of Carved Monuments and a Guide to the Visual Characteristics of Xochicalco's Art Style. In The Xochicalco Mapping Project, edited by Kenneth G. Hirth, pp. 17-56. Archaeological Research at Xochicalco, Vol. 2. University of Utah Press, Salt Lake City.

Solís Olguín, Felipe R., and Davíd A. Morales Gómez

1991 Rescate de un rescate: Colección de objetos arqueológicos de el Volador, ciudad de México. Catálogo de las colecciones arqueológicas de Museo Nacional de Antropología. Instituto Nacional de Antropología e Historia, Mexico City.

Stresser-Péan, Guy

1995 El Códice de Xicotepec: estudio e interpretación. Gobierno del Estado de Puebla, Centro Francés de Estudios Mexicanos y Centroamericanos, Fondo de Cultura Económica, Mexico City.

Taube, Karl A.

1988 A Study of Classic Maya Scaffold Sacrifice. In Maya Iconography, edited by Elizabeth P. Benson and Gillett G. Griffin, pp. 331351. Princeton University Press, Princeton, NJ.
1992 The Temple of Quetzalcoatl and the Cult of Sacred War at Teotihuacan. Res: Anthropology and Aesthetics 21:53-87.

1993 Aztec and Maya Myths. University of Texas Press, Austin.

2000 The Turquoise Hearth: Fire, Self Sacrifice, and the Central Mexican Cult of War. In Mesoamerica's Classic Heritage: From Teotihuacan to the Aztecs, edited by Davíd Carrasco, Lindsay Jones, and Scott Sessions, pp. 269-340. University Press of Colorado, Niwot.

Tena, Rafael

1987 El calendario mexica y la cronografía. Instituto Nacional de Antropología e Historia, Mexico City.

Umberger, Emily

1987a Antiques, Revivals, and References to the Past in Aztec Art. RES: Anthropology and Aesthetics 13:62-105.

1987b Events Commemorated by Date Plaques at the Templo Mayor: Further Thoughts on the Solar Metaphor. In The Aztec Tempo Mayor, edited by Elizabeth H. Boone, pp. 411-450. Dumbarton Oaks, Washington, DC.

1996 Art and Imperial Strategy in Tenochtitlan. In Aztec Imperial Strategies, by Frances F. Berdan, Richard E. Blanton, Elizabeth H. Boone, Mary G. Hodge, Michael E. Smith, and Emily Umberger, pp. 85-106. Dumbarton Oaks, Washington, DC.

Vaillant, George C.

1930 Excavations at Zacatenco. Anthropological Papers, Vol. 32, No. 1. American Museum of Natural History, New York.

1931 Excavations at Ticoman. Anthropological Papers, Vol. 32, No. 2. American Museum of Natural History, New York.

1935a Excavations at El Arbolillo. Anthropological Papers, Vol. 35, No. 2. American Museum of Natural History, New York.

1935b Untitled manuscript. In the collection of the American $\mathrm{Mu}$ seum of Natural History, New York.

1937 History and Stratigraphy in the Valley of Mexico. Scientific Monthly 44:307-324.

1938 A Correlation of Archaeological and Historical Sequences in the Valley of Mexico. American Anthropologist 40:535-573.

1941 Aztecs of Mexico: Origin, Rise and Fall of the Aztec Nation. Doubleday Doran, Garden City.

Vaillant, George C., and Suzannah B. Vaillant

1934 Excavations at Gualupita. Anthropological Papers, Vol. 35, No. 1. American Museum of Natural History, New York.

Vega Sosa, Constanza

1975 Forma y decoración en vasijas de tradición Azteca. Colección Científica, Vol. 23. Instituto Nacional de Antropología e Historia, Mexico City.

Von Winning, Hasso

1979 The Binding of the Years and the "New Fire" at Teotihuacan. Indiana 5:15-27

Welsh, W.B.M.

1988 An Analysis of Classic Lowland Maya Burials. BAR International Series, Vol. S409. British Archaeological Reports, Oxford.

Whalen, Michael E., and Jeffrey R. Parsons

1982 Ceramic Markers Used for Period Designations. In Prehispanic Settlement Patterns in the Southern Valley of Mexico: The ChalcoXochimilco Region, by Jeffrey R. Parsons, Elizabeth Brumfiel, Mary H. Parsons, and David J. Wilson, pp. 385-459. Memoirs of the Museum of Anthropology, Vol. 14. University of Michigan, Ann Arbor. 